\title{
Quantitative and Qualitative Assessment of Groundwater from Semi-Arid Zones in the Context of Climate Change, Example of Essaouira Region, Morocco
}

\author{
Mohammed Bahir ( $\sim$ bahir@uca.ac.ma ) \\ IWRI Universite Mohammed VI Polytechnique https://orcid.org/0000-0003-0041-9832 \\ Salah Ouhamdouch \\ Universite Cadi Ayyad \\ Driss Ouazar \\ IWRI Universite Mohammed VI Polytechnique \\ Nabil El Moçayd \\ IWRI Universite Mohammed VI Polytechnique
}

\section{Research article}

Keywords: Semi-arid zone, Global warming, Groundwater, Isotopy, Hydrogeochemistry

Posted Date: May 28th, 2020

DOl: https://doi.org/10.21203/rs.3.rs-31695/v1

License: (c) (i) This work is licensed under a Creative Commons Attribution 4.0 International License.

Read Full License 


\section{Abstract}

This study aims to assess the effect of climate change on water resources in semi-arid environments, taking the Essaouira region as an example. Analysis of climate data shows a downward trend in precipitation of 12 to $16 \%$ and an increase in air temperature of $2.3^{\circ} \mathrm{C}$ over the past three decades. The piezometric study shows a continuous drop in the piezometric level which exceeds $12 \mathrm{~m}$ for the Cenomanian-Turonian aquifer, $17 \mathrm{~m}$ for the Plio-Quaternary aquifer, around $8 \mathrm{~m}$ for the Barremian-Aptian aquifer and $5 \mathrm{~m}$ for the Hauterivian. Hydrogeochemical analysis shows that (i) the groundwater mineralization is controlled by the dissolution of evaporitic and carbonates minerals, by the reverse ions exchange phenomenon, and by the marine intrusion, especially at Plio-Quaternary aquifer; (ii) the groundwater quality in the study area deteriorates gradually over time and space. The isotopic technique shows that (i) the groundwater recharge in the study area is ensured by precipitation of oceanic origin without significant evaporation and that (ii) climate change has no remarkable effect on the isotopic content of the groundwater of the study area. However, the results of this article reflect that the Essaouira basin is very vulnerable to climate change.

\section{Introduction}

Climate change is a global problem, involving the long term complex interactions between environmental factors and economic, social, technological and political conditions which cause significant effects at regional level (Lebel and Vischel 2005; Alpert et al. 2008; Misra 2014), including the Maghreb region (Bahir et al. 2016; El Kharraz 2012; Ouhamdouch et al. 2018, 2020; Ragab and Prudhomme 2002).

In arid and semi-arid regions, rainfall is one of the determining factors of climatic characterization. The study of recent evolution in climate is an essential tool to determine optimal general solutions to the problems resulting from the relationship between water requirement and their availability, and therefore better management of water resource (Bahir et al. 2018, 2019; Carreira et al. 2018; Ragab and Prudhomme 2002).

Studies on climate change show that global warming in the Maghreb country is significant than the global average. Indeed, on a global scale, the increase estimated at $0.74{ }^{\circ} \mathrm{C}$ in the 20 th century, while it was oscillated between 1 and $2^{\circ} \mathrm{C}$ on the Mediterranean scale and the region of North Africa ( GIEC 2007; Green et al. 2011; Ouhamdouch et al. 2018, Ragab and Prudhomme 2002). As for precipitation, it has decreased in the Mediterranean region, in the Sahel, in southern Africa and in certain parts of South Asia at different temporal and spatial scales (Alpert et al. 2008; IPCC 2013).

Morocco, like the Mediterranean countries (Vicente-Serrano 2006), have suffered from several periods of drought (Bahir et al. 2002; Driouech 2010; Babqiqi 2014). Its water resources are limited; they are estimated at 20 billion cubic meters, or an average of $700 \mathrm{~m}^{3} / y e a r /$ inhabitant, which corresponds to a situation of fairly high water stress. The number of years in rainfall deficit is greater than the number of wet years (Driouech 2010; Stour and Agoumi 2009; Sinan et al. 2009), especially the cycles of 1980- 
1985, 1990-1995 and 2007-2010. According to Babqiqi (2014), the comparison of the average annual temperatures over the two periods 1971-1980 and 1998-2007 shows an increasing trend (from 0.3 to $2.5^{\circ} \mathrm{C}$ depending on the region).

This decrease in precipitation and the increase in temperatures linked to the climate change are likely to have a negative impact on water resources, especially in arid and semi-arid areas.

In these regions, few studies have been done to assess the climate change impact on water resources, but they are generally focused on surface water (Abutaleb et al. 2018; Hallouz et al. 2019; Xu et al. 2004). Some other studies studies have evaluated the global warming effect on groundwater by limiting ourselves to the piezometric and/or hydrochemical approach (Al-Maktoumi et al. 2018; Berhail 2019; Lachaal et al. 2018). For this study to be original, we assessed the impact of climate change on the water resource of the Essaouira basin (Morocco) by combining several approaches such as hydroclimatology, piezometry, hyrochemistry and isotopy.

\section{Study area}

The study area, called the Essaouira syncline basin, covers an area of $6000 \mathrm{~km}^{2}$. It is part of the Atlantic Atlas, which is the westernmost part of the southwestern Moroccan basin (Dresh 1962; Duffaud 1960). This basin is bounded to the north by Hadid anticline, to the south by Tidzi wadi, to the east by the Bouabout region, and to the west by the Atlantic Ocean. It is subdivided into two parts, the first known as the "Bouabout unit" (upstream part) and the second known as the "coastal zone" (downstream part) (Fig.1).

From a morphological point of view, the study area is made up of a set of synclinal basins filled with formations ranging from the Triassic to the Quaternary (Fig.2). The elevations vary between 400 and $1600 \mathrm{~m}$ for the upstream part and less than $400 \mathrm{~m}$ for the downstream part. Hydrographically, the study area is characterized by a less-developed network. This is mainly represented by Ouazzi wadi in the North and Igouzoullene wadi in the South, passing through Ksob wadi resulting from the confluence of Igrounzar and Zelten wadi and through Tidzi wadi. All of these wadis flow into the Atlantic Ocean (Fig.2).

Geologically and hydrogeologically, the upstream part of the study area is marked by the outcrop of formations of Middle and Upper Cretaceous age, in particular, Albian-Vraconian, Cenomanian and Turonian (Duffaud 1960; Amghar 1989) (Fig.3). These formations are composed of limestone and dolomitic benches interspersed with marl and sandstone. The Albian-Vraconian formations contain sandstone and limestone dolomites alternating with sandstone banks and sandy clays.

The Cenomanian (about $200 \mathrm{~m}$ thickness) is represented by alternating marls with anhydrite, lumachellic and dolomitic limestones. As for the Turonian, it is composed of limestones with an abundance of silica. These synclines contain important water reservoirs, notably the Cenomanian-Turonian aquifer which 
remains the most important in the region. According to Jalal et al. (2001), this aquifer has transmissivities varying between $2.2 * 10^{-4}$ and $2.7 * 10^{-1} \mathrm{~m}^{2} / \mathrm{s}$.

The downstream part contains 2 important aquifers: (i) the Plio-quaternary and the (ii) Turonian in the northern part, between Ksob wadi and Tidzi wadi, (iii) the Barremian-Aptian located between Tidzi wadi and Amssittene anticline and (iv) the Hauterivian, southern limit of the study area, is interposed between the Amssittene anticline and Igouzoullene wadi (Fig.2).

The Plio-quaternary is characterized by a matrix of limestone sandstone. It contains an important water table, the wall of which is formed in the synclinal structure by the marls of Senonian (Fig.3).

According to Mennani (2001), this water table has transmissivities varying between $6.1 * 10^{-2}$ and $4.5^{\star} 10^{-}$ ${ }^{5} \mathrm{~m}^{2} / \mathrm{s}$.

As for the Turonian, represented by limestones, it contains a captive aquifer under the Senonian marls in the synclinal structure and probably in direct contact with the Plio-Quaternary at the confines of this structure (Fig.3). It has a transmissivity ranging between $0.8 * 10^{-4}$ and $2.7 * 10^{-2} \mathrm{~m}^{2} / \mathrm{s}$ (Mennani 2001).

The Barremo-Aptian aquifer contains Barremian formations (about $70 \mathrm{~m}$ thickness) represented by an alternation of gray marl (with traces of gypsum), fractured fossiliferous limestones and sandstone and Aptian formations (about $100 \mathrm{~m}$ thickness) composed of red clays and sandstone with intercalations of dolomitic sandstones or bioclastic limestones (Duffaud 1960; Duffaud et al. 1966) (Fig.3). The transmissivity is of the order of $1.5^{\star} 10^{-3} \mathrm{~m}^{2} / \mathrm{s}$ (Mennani 2001).

The Hauterivian aquifer, whose thickness is about $200 \mathrm{~m}$, is composed of marly clays and fractured siliceous limestones, marly and dolomitic limestones more or less fractured (Fig.3) (Duffaud 1960; Duffaud et al. 1966). According to Mennani (2001), this aquifer has transmissivities varying between $1.6 * 10^{-5}$ and $6.7 * 10^{-5} \mathrm{~m}^{2} / \mathrm{s}$.

\section{Materials And Methods}

In this investigation, the results of nine campaigns 1990, 1995, 1997, 2009, 2015, 2016, 2017, 2018 and 2019 were used to assess the quality of groundwater in the Essaouira region in the context of climate change. Electrical conductivities, temperatures, $\mathrm{pH}$ and nitrates were measured in situ with a portable conductivity meter (HI9829 multiparametric instrument), and the depth of the water level was measured using a $200 \mathrm{~m}$ piezometric probe.

The analyses of the chemical elements were carried out at the Laboratory of Hydrogeology at the Faculty of Sciences Semlalia of Marrakech (Morocco) for the campaigns 1990 to 2009. As for that of 2015 to 2019, the analyses were carried out at the Laboratory of Geosciences and Environment- ENS at the Ecole Normale Superieure of Marrakech (Morocco). The $\mathrm{SO}_{4}{ }^{2-}$ anion contents were determined by the nephelometric method (Rodier et al. 2009). Concentrations of $\mathrm{Ca}^{2+}$ and $\mathrm{Mg}^{2+}$ cations were measured by 
the complexometry method (EDTA) and those of $\mathrm{Cl}^{-}$by the Mohr method (Rodier et al. 2009). The $\mathrm{Na}^{+}$and $\mathrm{K}^{+}$contents were determined by flame photometry (Rodier et al. 2009). As for $\mathrm{HCO}_{3}{ }^{-}$contents, they were determined by titration using a sulfuric acid solution. All the samples display an ion balance of less than $10 \%$, which allowed us to validate the obtained results. The obtained results are grouped in Appendix 1.

A total of 46 points collected, in April 2016 (22 points) and in May 2018 (24 points) were analyzed for stable isotopes (oxygen-18 and deuterium) and radioactive (Tritium). The 22 samples taken in 2016 represent the Cenomanian-Turonian aquifer (the upstream part of the study area) and 24 water points taken in 2018 represent the Plio-Quaternary aquifer (18 samples), 4 the Turonian aquifer (4 samples) and surface water (2 samples).

The analysis of stable isotopic elements $\left(\delta^{2} \mathrm{H}\right.$ and $\left.\delta^{18} \mathrm{O}\right)$ were carried out at the Nuclear Technology Institute in Lisbon (Portugal) and the Laboratory of Radio-Analysis and Environment (LRAE) at the National School of Engineers of Sfax (Tunisia) by applying the mass spectrometry method (Friedman et al. 1953; Epstein and Mayeda 1953). The tritium $\left({ }^{3} \mathrm{H}\right)$ content was determined by the technique of electrolytic enrichment followed by the liquid scintillation counting method (Lucas and Unterweger 2000) at Nuclear Technology Institute in Lisbon (Portugal).

A Geographic Information System (GIS) was used to map the spatial distribution maps of the electrical conductivity and the physicochemical elements.

The PHREEQC program (Parkhurst and Appelo 1999) was used to calculate the saturation indices (SI) using the following formula: $\mathrm{SI}=\log (\mathrm{KIAPKSP})$

With: $\mathrm{K}_{\mathrm{IAP}}$ is the product of the ionic activity of ions. $\mathrm{K}_{\mathrm{SP}}$ is the mineral solubility product. The saturation index corresponds to the deviation from the equilibrium of the water from the mineral phase. If $\mathrm{SI}=0$, the water is in equilibrium; $\mathrm{SI}$ is negative, the water is undersaturated with respect to the mineral; $\mathrm{SI}$ is positive, the water is supersaturated with respect to this mineral.

\section{Results And Discussion}

\section{Climatic parameters (Precipitations and temperatures)}

The climate parameter data used in this study were obtained from the Tensift Hydraulic Basin Agency (ABHT).

Analysis of precipitation data for an observation period of 38 years (1978-2015) for the study area reveals significant variability on an annual scale (Fig.4).

Indeed, this rainfall is subject to fluctuations from one year to another, with wet and other dry periods of two to five consecutive years. The height of the precipitated sheet of water varies between a minimum of $135 \mathrm{~mm}$, measured in 2008 and a maximum of $707 \mathrm{~mm}$ measured in 1996 with an average of $304 \mathrm{~mm}$. 
The application of the Pettitt test (Pettitt 1979) (Table 1), with a 90\% confidence level shows the presence of a break in the pluviometric series in 1999. This test made it possible to split the rainfall series into two sub-series. The average of annual rainfall before and after this break is $A_{1}=313.8$ (first sub-series) and $A_{2}=263.4$ (second sub-serie) $\mathrm{mm}$, respectively. This makes it possible to estimate a rainfall deficit of $16 \%$. The results of the Mann-Kendall trend test (Table 1) displays a negative multivariable standard normal $\left(U_{M K}\right)\left(U_{M K}=-1.09\right)$. This reflects a downward trend in precipitation and confirms the results of the Pettitt test.

Table 1. Statistical tests

\begin{tabular}{|c|c|c|}
\hline Test & Formula & Reference \\
\hline Pettitt & $\begin{array}{c}\mathrm{U}_{\mathrm{tT}}=\sum_{\mathrm{l}=1} \sum_{\mathrm{l}=+1} \mathrm{Dij} \\
\text { With: } \mathrm{Dij}=-1 \text { si }(\mathrm{xi}-\mathrm{xj})>0, \mathrm{Dij}=0 \text { si }(\mathrm{xi}-\mathrm{xj})=0, \mathrm{Dij}=1 \mathrm{si}(\mathrm{xi}-\mathrm{xj})>0 .\end{array}$ & Pettitt 1979 \\
\hline Mann-Kendall & $\begin{array}{c}\mathrm{U}_{\mathrm{MK}}=\frac{\mathrm{S}}{\sqrt{\operatorname{Var}(s)}} \\
\text { With }: \mathrm{S}=\sum_{\mathrm{i}=1}^{\mathrm{n}-1} \sum_{\mathrm{j}=\mathrm{i}+1}^{\mathrm{n}} \operatorname{sgn}\left(\mathrm{a}_{\mathrm{j}}-\mathrm{a}_{\mathrm{j}}\right) \text { and } \operatorname{Var}(\mathrm{s})=\frac{\mathrm{n}(\mathrm{n}-1)(2 \mathrm{n}+5)}{18} \\
\text { The trend is upward if } \mathrm{U}_{\mathrm{MK}}>0 \text {, downward if } \mathrm{U}_{\mathrm{MK}}<0\end{array}$ & $\begin{array}{l}\text { Mann } 1945 \\
\text { Kendall } 1975\end{array}$ \\
\hline
\end{tabular}

The evolution study of annual atmospheric temperatures was carried out over for 28 years (1987-2015). Maximum temperatures range between 29.3 and $37.2^{\circ} \mathrm{C}$ with an average of $34.2^{\circ} \mathrm{C}$. As for the minimum temperatures, they range between 2.4 and $9.3^{\circ} \mathrm{C}$ with an average of $7.4^{\circ} \mathrm{C}$. While the average temperatures, vary between 17.7 and $22.4^{\circ} \mathrm{C}$ with an average of $20^{\circ} \mathrm{C}$ (Fig.5a).

The application of the Pettitt test with a significance level equal to $5 \%$ shows the existence of a significant break in the series of maximum, average and minimum annual temperatures, respectively in 1999, 2000 and 1994 (Fig.5b). For the maximum annual temperatures, the average before and after this break is 32.75 and $35.53^{\circ} \mathrm{C}$, with an increase of $2.8^{\circ} \mathrm{C}$. As for the mean annual temperatures, the average before and after the break equal to 18.85 and $21.13^{\circ} \mathrm{C}$, respectively, with a warming of $2.3^{\circ} \mathrm{C}$. For minimum annual temperatures, the average before and after the break is 5.66 and $8.14{ }^{\circ} \mathrm{C}$, respectively, with an increase of $2.5^{\circ} \mathrm{C}$. The rupture date of the maximum and the mean temperature series are approximately the same and this could be explained by the fact that these two parameters exhibit the same evolution during the study period. As for the series of minimum temperatures, it presents an early break (1994). This could be explained by the very cold temperatures experienced by the study area in 1988,1989 and 1990 (start of the series).

This upward trend is corroborated by the Mann-Kendall test with a positive multivariable standard normal $U_{M K}$ for annual maximum temperatures $\left(U_{M K}=+5.24\right)$, for annual mean temperatures $\left(U_{M K}=+5.65\right)$ and annual minimum temperatures $\left(U_{\mathrm{MK}}=+4.65\right)$.

The Gaussen diagram corresponds to the intersection of the monthly average precipitation curve and the monthly average temperature curve for the same station. When the precipitation curve is above that of 
temperatures, we talk about a wet period. While the dry period takes place when the precipitation curve is below that of temperatures.

This diagram distinguishes a dry period from a wet period (Bagnouls and Gaussen 1953; Daget 1977; Hannachi and Fenni 2013). For this study and during the period 1987-2000, Figure 6 shows a dry period from April to September and a wet period from October to March. However, groundwater recharge could, therefore, take place mainly during this wet period. By comparing the length of the dry period during the two periods 1987-2000 and 2001-2014, we can see that it experienced an extension of about one month. This will undoubtedly influence the groundwater recharge.

\section{Piezometry}

The evolution of the groundwater piezometric surface is closely related to the variation of precipitation (Bahir et al. 2016; Ouhamdouch et al. 2016), the degree of exploitation and the contributions of surface water.

The piezometric maps drawn up from the data of September 1990, June 1995, March 1997, October 2007, June 2015, April 2016, April 2017, May 2018 and March 2019 companions for the aquifers of the Essaouira basin, show that:

-For the upstream part of the basin, the groundwater has a general flow direction from SE to NW for the southern part and from NE-SW for the northern part (Fig.7a). This flow is conditioned by the substratum of the reservoir studied. Over a 24-year observation period (1995-2019), the groundwater maintains the same direction of flow with a decline in the piezometric level. This drawdown is manifested, for example, by the offset of the piezometric curves 450 and $600 \mathrm{~m}$ more and more upstream, and this on the two piezometric maps (Fig.7a). Monitoring the evolution of the piezometric level of the wells whose water level was measured during October 2007, April 2016, April 2017, May 2018, and March 2019 is shown in the Figure 8. This shows that all of the wells have suffered a decline in their piezometric levels. It reached $9.3 \mathrm{~m}$ at well 030 and $12.6 \mathrm{~m}$ at well 75/52 between 2007 and 2019 .

-For the downstream part, the general direction of groundwater flow of the Plio-Quaternary aquifer and that of the Barremian-Aptian is generally from south-east to north-west (Fig.7b and C). The groundwater flow within the Plio-Quaternary aquifer is imposed by the inclination of its substratum, while for the Barremian-Aptian, the flow is imposed by the north flank of the Amssittene anticline and the uplift of the substratum of the lower Cretaceous formations. Concerning the Hauterivian aquifer, the general direction of flow is from the northeast to the southwest and this follow the southern flank of the Amssittene anticline. The same remark observed for the downstream part, the groundwater keeps the same direction of the flow with a decline in the piezometric level. Over a 29-year observation period (1990-2019) (Fig.7b), the groundwater of the Plio-Quaternary aquifer keeps the same direction of flow with a decent piezometric level. This situation is materialized, for example, by the shift of the isopiezes 40 and $180 \mathrm{~m}$ more and more upstream, and this on the two piezometric maps. The evolution of the piezometric level of 
the wells capturing this aquifer and having experienced measurements of their water body during 1990, 1995, 2000, 2004, 2009, 2015, 2017, 2018 and 2019 (Table 2) shows a reduction in the plan of water at these wells. It reached $17 \mathrm{~m}$ at well 261/51 and $6.6 \mathrm{~m}$ at well 140/51, between 1990 and 2019. The drought of 1995, the driest year in Morocco during the 20th century, led to a general decline in the water level.

Over a 43-year observation period (1976-2019) (Fig.7c), the groundwater of the Barremian-Aptian and Hauterivian aquifer keeps the same direction of flow with a decent piezometric level. With a total of nine wells, in which six wells capture the Barremian-Aptian aquifer and three captures the Hauterivian aquifer, having experienced measurements of their water body during 1976, 1997, 2015, 2017, 2018 and 2019, the study of the groundwater level of the aforementioned aquifers shows a decrease in piezometric levels (Table 3). For the Barremian-Aptien aquifer, it reached $9.1 \mathrm{~m}$ at well $176 / 51$ and $8.8 \mathrm{~m}$ at well $173 / 51$, between 1976 and 2019, i.e. an average annual decrease of $0.2 \mathrm{~m}$. As for the Hauterivian aquifer, this reduction reached $4.8 \mathrm{~m}$ at the level of well P6 and $3 \mathrm{~m}$ at the level of well 193/51, i.e. an average annual decrease of 0.11 and $0.07 \mathrm{~m}$ respectively.

Following the absence of industrial activity in the study area and the agricultural activity of "food type" practiced by the population, the decrease in the piezometric level could only be explained by the decrease in precipitation under the effect of climate change.

\section{Hydrogeochemistry}

A hydrogeochemical approach is a valuable tool for characterizing groundwater chemistry. The latter is largely influenced by the characteristics of the host rock, the hydrodynamics of the aquifers and also by the climatic and exploitation conditions.

\section{Chemical facies}

To specify the groundwater chemical facies in the study area, the major element composition has been plotted on the Piper diagram (Piper 1944).

-For the Cenomanian-Turonian aquifer, representing the upstream part of the basin studied, the projection of the analysed samples on the Piper diagram (Fig.9a) shows that the waters have a mixed facies between $\mathrm{Cl}-\mathrm{Na}, \mathrm{Cl}-\mathrm{Ca}-\mathrm{Mg}, \mathrm{SO}_{4}-\mathrm{Ca}-\mathrm{Mg}$, and $\mathrm{HCO}_{3}-\mathrm{Ca}-\mathrm{Mg}$. In 1995, the majority of the samples presented a $\mathrm{Cl}-\mathrm{Ca}-\mathrm{Mg}$ facies. For the samples of the 2007 campaign, the chemical facies of the waters are of $\mathrm{Cl}-\mathrm{Ca}$ $\mathrm{Mg}, \mathrm{SO}_{4}-\mathrm{Ca}-\mathrm{Mg}$ and $\mathrm{HCO}_{3}-\mathrm{Ca}-\mathrm{Mg}$ type with the dominance of the $\mathrm{Cl}-\mathrm{Ca}-\mathrm{Mg}$ type. As for the samples analysed in 2016, they have a facies of $\mathrm{Cl}-\mathrm{Na}$ type and of the $\mathrm{Cl}-\mathrm{Ca}-\mathrm{Mg}$ and $\mathrm{SO}_{4}$-Ca-Mg type. For the 2017, 2018 and 2019 campaigns, we note that the analysed waters present three types of facies: $\mathrm{Cl}-\mathrm{Na}, \mathrm{Cl}-\mathrm{Ca}-$ $\mathrm{Mg}, \mathrm{SO}_{4}-\mathrm{Ca}-\mathrm{Mg}$, and $\mathrm{HCO}_{3}-\mathrm{Ca}-\mathrm{Mg}$ with the dominance of the $\mathrm{Cl}-\mathrm{Ca}-\mathrm{Mg}$ type. A comparison of the results 
of the 1995 campaign and those of 2019 (Fig.9b) shows that the groundwater facies of the CenomanianTuronian aquifer have not experienced any remarkable change.

-For groundwater of the downstream part, the analysis of the Piper diagrams for the Plio-Quaternary and Turonian aquifers (Fig.10a and b) shows that they are classified under a mixed facies between $\mathrm{Cl}-\mathrm{Na}$ and $\mathrm{Cl}-\mathrm{Ca}-\mathrm{Mg}$. The regrouping of the points of the Plio-Quaternary aquifer near the Turonian aquifer suggests an interconnection between these two aquifers.

The comparison between the results of 1990 and 2019 is presented in Figure 10c. This shows that there is a slight evolution in the chemical facies of the Plio-Quaternary groundwater. Indeed, on the cations triangle concerning the 1990 campaign, the majority of the points have a percentage higher than $50 \%$ in $\mathrm{Na}^{+}$with a tendency towards the $\mathrm{Na}$ pole. However, in 2019, the majority of the points do not exceed $50 \%$ in $\mathrm{Na}^{+}$with a tendency towards the center of the sorting "no dominant cations". For the anion triangle, a clear dominance of $\mathrm{Cl}^{-}$is noted, whether in 1990 or in 2019. The position of certain samples relative to the sample representing seawater on the Piper diagram suggests that the Plio-Quaternary aquifer is probably affected by the marine intrusion.

The groundwater of the Barremian-Aptian and those of the Hauterivian generally present three types of chemical facies: $\mathrm{Cl}-\mathrm{Na}, \mathrm{Cl}-\mathrm{Ca}-\mathrm{Mg}$, and $\mathrm{HCO}_{3}-\mathrm{Ca}-\mathrm{Mg}$ with the dominance of the second facies (Fig.11a and b). The dominance of $\mathrm{Cl}$ over $\mathrm{HCO}_{3}$ could be explained by the influence of Triassic saliferous formations. The comparison between the water points sampled in 1997 and 2019 (Fig.11c) shows a remarkable evolution in the groundwater chemistry of the Barremian-Aptian and Hauterivian aquifers from the mixed facies $\mathrm{Cl}-\mathrm{Na}$ and $\mathrm{Cl}-\mathrm{Ca}-\mathrm{Mg}$ to the facets $\mathrm{Cl}-\mathrm{Ca}-\mathrm{Mg}$.

\section{Groundwater mineralization}

To determine the origin and the main processes responsible for the groundwater mineralization of the study area, the correlations between the main major elements have been studied.

Chloride is a conservative ion that is always found in natural waters at very variable contents (Fetter 1993) and sodium is generally associated with chlorides. Chlorides concentrations in groundwater of the upstream part vary widely from 113 to $1818 \mathrm{mg} / \mathrm{l}$ with an average of $574 \mathrm{mg} / \mathrm{l}$. As for those of sodium, they vary between 12 and $541 \mathrm{mg} / \mathrm{l}$ with an average of $167 \mathrm{mg} / \mathrm{l}$. According to the Piper diagram (Fig.9), it can be seen that the $\mathrm{Cl}^{-}$ions are the most dominant in the waters. For the downstream part, the $\mathrm{Cl}^{-}$ contents vary between 120 and $4800 \mathrm{mg} / \mathrm{l}$ with an average of $620 \mathrm{mg} / \mathrm{l}$ and the $\mathrm{Na}^{+}$concentrations vary between 28 and $1950 \mathrm{mg} / \mathrm{l}$ with an average of $261 \mathrm{mg} / \mathrm{l}$. The highest $\mathrm{Na}^{+}$and $\mathrm{Cl}^{-}$contents are observed at the Plio-Quaternary aquifer.

The $\mathrm{Na}^{+} \mathrm{vs} \mathrm{Cl}^{-}$correlation diagram (Fig.12a) shows a significant positive correlation between these two ions. This reflects that these two elements probably have the same origin. Some points are scattered around the halite dissolution line (line 1:1), reflecting the contribution of this mineral in the groundwater 
mineralization of the study area. This hypothesis is confirmed by negative values of the saturation indices with respect to this mineral (Fig.13). The rest of the samples are located below the line 1:1 and parallel to it, reflecting a $\mathrm{Na}^{+}$deficit. This suggests the contribution of a phenomenon other than the halite dissolution in the groundwater mineralization.

The $\mathrm{Na}^{+}$deficit compared to $\mathrm{Cl}^{-}$could be linked to the basic exchange reactions, as shown in the Figure $12 \mathrm{f}$, with the aquifer matrix where the $\mathrm{Na}^{+}$ions are released from the complex and are replaced by $\mathrm{Ca}^{2+}$ ions according to equation (1) (Capaccioni et al. 2005):

\section{$\mathrm{Na}++12 \mathrm{Ca}-\mathrm{X} 2 \rightarrow \mathrm{Na}-\mathrm{X}+12 \mathrm{Ca}+(1)$}

With $\mathrm{X}$ being the natural exchanger

Also, an excess of $\mathrm{Na}^{+}$could be explained by the second type of cations exchange where the $\mathrm{Ca}^{2+}$ and/or $\mathrm{Mg}^{2+}$ ions will be released in water and the $\mathrm{Na}$ ions will be fixed by the matrix according to equation (2):

\section{$12 \mathrm{Ca} 2++\mathrm{Na}-\mathrm{X} \rightarrow 12 \mathrm{Ca}-\mathrm{X} 2+\mathrm{Na}+(2)$}

The $\mathrm{Ca}^{2+}$ contents of the groundwater from the upstream part vary between 82 to $770 \mathrm{mg} / \mathrm{l}$ with an average of $214 \mathrm{mg} / \mathrm{l}$. As for those of $\mathrm{SO}_{4}{ }^{2-}$, they vary between 13 and $1942 \mathrm{mg} / \mathrm{l}$ with an average of 339 $\mathrm{mg} / \mathrm{l}$. As for the downstream part, the $\mathrm{Ca}^{2+}$ concentrations oscillate between 64 and $850 \mathrm{mg} / \mathrm{l}$ with an average of $158 \mathrm{mg} / \mathrm{l}$ and those of $\mathrm{SO}_{4}{ }^{2-}$ vary between 30 and 830 with an average of $147 \mathrm{mg} / \mathrm{l}$.

Figure $12 \mathrm{~b}$ shows the existence of a significant correlation between the $\mathrm{Ca}^{2+}$ and $\mathrm{SO}_{4}{ }^{2-}$ ions. Indeed, the points whose $\mathrm{Ca}^{2+} / \mathrm{SO}_{4}{ }^{2-}$ molar ratio is close to or equal to 1 , reflect the same origin of these two ions which could be the dissolution of gypsum and/or anhydrite. This is confirmed by negative values of the indices of saturation with respect to gypsum and/or anhydrite (Fig.13). However, the excess of $\mathrm{Ca}^{2+}$ compared to $\mathrm{SO}_{4}{ }^{2-}$ observed for the majority of the points could be linked to the phenomenon of reverse bases exchange. Also, the saturation indices calculated for these points with respect to carbonate minerals are close to or greater than zero, corroborating that the enrichment of $\mathrm{Ca}^{2+}$ is mainly due to the bases exchange (Fig.12f).

The $\mathrm{Ca}^{2+}$ vs $\mathrm{Mg}^{2+}$ diagram (Fig.12c) shows a positive correlation between these two ions, this reflects that these two elements come from the same origin. The majority of the points are scattered around the dolomite dissolution line (line 1:1), thus suggesting the contribution of the dissolution of this mineral to the groundwater mineralization. Other points are located above the line 1:1, confirming the contribution of the bases exchange process in the groundwater mineralization of the aquifers studied. 
The $\mathrm{Ca}^{2+}{ }^{2} \mathrm{v} \mathrm{HCO}_{3}{ }^{-}$correlation (Fig. $12 \mathrm{~d}$ ) shows that these two elements do not have a significant correlation and that the majority of the analyzed samples show a Ca ${ }^{2+} / \mathrm{HCO}_{3}^{-}$molar ratio greater than 1 . This excess of $\mathrm{Ca}^{2+}$ compared to $\mathrm{HCO}_{3}{ }^{-}$ions translates the existence of other sources of calcium which could be the phenomenon of ion exchange and that of dedolomitization (incongruent dissolution of dolomite) (Marfia et al. 2004) accompanied by simultaneous precipitation of calcite.

\section{Nitrates contamination}

The main source of nitrate in water is the leaching of nitrogenous products in the soil following the decomposition of organic matter or synthetic and/or natural fertilizers. The nitrate content of unpolluted natural waters is highly variable, varying from 1 to $15 \mathrm{mg} / \mathrm{l}$ depending on the season and the origin (Chenaker et al. 2017).

The $\mathrm{NO}_{3}{ }^{-}$contents in groundwater of the Cenomanian-Turonian aquifer (upstream part) measured in March 2019 vary from 0 to $175 \mathrm{mg} / \mathrm{l}$ with a punctual spatial distribution (Fig.14a). Generally, levels are high in the Meskala region and exceed the threshold $(50 \mathrm{mg} / \mathrm{l})$ set by the World Health Organization (WHO 2011). Also, high values have been noted in some other wells such as 613/52 upstream 037 and $75 / 52$ west of the Kourimat and 056 downstream.

For the Plio-Quaternary and Turonian aquifers, the $\mathrm{NO}_{3}{ }^{-}$contents vary, respectively between 0 and 400 $\mathrm{mg} / \mathrm{l}$ and between 0 and $65 \mathrm{mg} / \mathrm{l}$ (Fig. 14b). As for the Barremian-Aptian aquifer, it has $\mathrm{NO}_{3}{ }^{-}$contents varying between 5 and $60 \mathrm{mg} / \mathrm{l}$. While the Hauterivian, has concentrations varying between 3 and $16 \mathrm{mg} / \mathrm{l}$ (Fig.14c).

The very weak correlation between $\mathrm{Cl}^{-}$and $\mathrm{NO}_{3}{ }^{-}$(Fig.12e) makes it possible to say that the levels of $\mathrm{NO}_{3}{ }^{-}$ assayed in the samples analyzed are not of agricultural origin since the chlorides are due to the dissolution of the evaporate minerals.

The highest concentrations within the Plio-Quaternary aquifer are recorded in the southwest part, near Cap Sim (wells 11/51, 094 and 095) and in the northwest; tourist area of the Diabate (well 149/51). These high levels could be explained by the intense concentration of septic tanks constructed by the guest houses in the tourist area of Sidi Kaouki because of the absence of a sanitation network. As for the Turonian and Barremian-Aptian aquifers, only two points for each aquifer have levels exceeding the limit set by WHO (2011). The high grades at well P5 (Barremian-Aptian aquifer) are caused by the public waste dump of the Smimou center because this dump is located a few meters from this water point. Regarding the Hauterivian aquifer, all the samples have $\mathrm{NO}_{3}{ }^{-}$concentrations of less than $50 \mathrm{mg} / \mathrm{l}$. The low $\mathrm{NO}_{3}{ }^{-}$ concentrations in Hauterivian aquifer compared with the other aquifers could be explained by a low concentration of the population in this zone. 
The contamination ( $<50 \mathrm{mg} / \mathrm{l})$ of the other wells at the level of the aquifers studied could be explained by traditional methods of drawing. These result in a significant amount of water flowing around the catchment wells, constituting quasi-permanent pools that are enriched in $\mathrm{NO}_{3}{ }^{-}$by livestock waste during watering. Note also that the number of contaminated wells in the Plio-Quaternary and Turonian aquifer (northern part of the downstream part) is greater than that of the Barremian-Aptian and Hautarivian aquifers (southern part of the downstream part). This is mainly due to the concentration of inhabitants in the northern part, where the water points are located in the middle of the agglomerations, while in the southern part and because of highly uneven geology, most wells are far from the places habitat.

\section{Evolution of groundwater salinity}

The groundwater salinization is a very marked phenomenon in areas of water scarcity, especially the Saharan, arid and semi-arid zones. The scarcity or even the absence of surface water and the increasing demand for water as well as the decrease in precipitation have created enormous pressures on groundwater which have thus resulted in the degradation of their quality.

The spatial-temporal distribution of salinity was studied to assess the impact of climate change on the groundwater quality by using the results of the campaigns of 1995, 2007, 2016, 2017, 2018, and 2019. For the upstream part, the 1995 campaign shows the salinity values vary between 0.2 and $1.9 \mathrm{~g} / \mathrm{l}$ with an average of $0.7 \mathrm{~g} / \mathrm{l}$. In 2007, the salinity values fluctuated between 0.5 and $2.4 \mathrm{~g} / \mathrm{l}$ with an average of 1.1 $\mathrm{g} / \mathrm{l}$. As for the 2016 campaign, its values vary between 0.3 and $4.6 \mathrm{~g} / \mathrm{l}$ with an average of $1.37 \mathrm{~g} / \mathrm{l}$. For the 2017 campaign, the salinity fluctuates between 0.3 and $4 \mathrm{~g} / \mathrm{l}$ with an average of $1.29 \mathrm{~g} / \mathrm{l}$. In 2018 , the salinity values vary between 0.4 and $4.3 \mathrm{~g} / \mathrm{l}$ with an average of $1.4 \mathrm{~g} / \mathrm{l}$ and between 0.35 and $4.4 \mathrm{~g} / \mathrm{l}$ with an average of 1.4 for samples from the 2019 campaign (Fig.15).

From the analysis of the maps in Figure 15, it can be seen that the salinity values become more important by advancing in time and going from east to west and this during the six campaigns. Taking, for example, the region of Sebt Kourimat, recharge area of the Cenomanian-Turonian aquifer, the salinity values fluctuate around $0.46 \mathrm{~g} / \mathrm{l}$ in 1995 to reach $2.9 \mathrm{~g} / \mathrm{l}$ in 2019 . However, the general spatial-temporal evolution of salinity shows an increasing trend.

For the downstream part, the groundwater from the Plio-Quaternary aquifer has salinity values varying between 0.6 and $3.4 \mathrm{~g} / \mathrm{l}$ with an average of $1.7 \mathrm{~g} / \mathrm{l}$ in 1990, between 0.9 and $3 \mathrm{~g} / \mathrm{l}$ with an average of 1.6 $\mathrm{g} / \mathrm{l}$ in 1995 , from 0.4 to $4.1 \mathrm{~g} / \mathrm{l}$ with an average of $1.3 \mathrm{~g} / \mathrm{l}$ in 2004 , between 0.9 to $2.2 \mathrm{~g} / \mathrm{l}$ with an average of $1.4 \mathrm{~g} / \mathrm{l}$ in 2009, from 0.3 to 4.7 with an average of $1.5 \mathrm{~g} / \mathrm{l}$ in 2015 , between 0.4 and $4.8 \mathrm{~g} / \mathrm{l}$ with an average of $1.53 \mathrm{~g} / \mathrm{l}$ in 2017, between 0.5 and $6.5 \mathrm{~g} / \mathrm{l}$ with an average of $1.6 \mathrm{~g} / \mathrm{l}$ in 2018 and between 0.46 and $8.4 \mathrm{~g} / \mathrm{l}$ with an average of $1.7 \mathrm{~g} / \mathrm{l}$ in 2019 (Fig.16). From the maps of Figure 16, the highest values are observed in the southern and western part and this further to the remoteness to the recharge zones, to the residence time, to the influence of the Triassic terrains, and to the influence from the sea (marine intrusion (well 11/51)). While the low values of salinity are recorded in the north (along the Ksob wadi) and in the east of the Plio-Quaternary aquifer which represent the recharge zones. These low values are 
due to the fact that these places represent the recharge zones of this aquifer. The temporal evolution of groundwater salinity of the Plio-Quaternary aquifer shows an upward trend going from year to year and consequently deterioration in the groundwater quality. As for the Turonian aquifer, the minimum values of salinity are around $0.8 \mathrm{~g} / \mathrm{l}$ and the maximum values are around $1.3 \mathrm{~g} / \mathrm{l}$ with an average of $1.1 \mathrm{~g} / \mathrm{l}$, and this for 2004, 2009, 2015, 2017, 2018 and 2019 campaigns (Fig.16). The temporal evolution of the groundwater salinity of this aquifer does not show a significant trend, this could be explained by its significant depth and its captive nature.

Concerning the Barremian-Aptian aquifer, the salinity values vary between 0.2 and $3.2 \mathrm{~g} / \mathrm{l}$ with an average of $1.1 \mathrm{~g} / \mathrm{l}$ for the points representing the 1997 campaign, from 0.3 to $2.1 \mathrm{~g} / \mathrm{l}$ with an average of $1.1 \mathrm{~g} / \mathrm{l}$ for the samples collected in 2015 and 2017, between 0.4 to $2.8 \mathrm{~g} / \mathrm{l}$ with an average of $1.1 \mathrm{~g} / \mathrm{l}$ for the points of 2018 campaign waters and between 0.7 and $2.4 \mathrm{~g} / \mathrm{l}$ with an average of $1.2 \mathrm{~g} / \mathrm{l}$ for 2019 campaign (Fig.17).

The spatial-temporal distribution of the groundwater salinity of the Barremian-Aptian aquifer (Fig.17) shows a slight upward trend in the minimum values of the salinity while the maximum values have experienced slight stability. For the Hauterivian aquifer, the salinity values vary between 0.6 to $2.6 \mathrm{~g} / \mathrm{l}$ with an average for waters representing the 1997 campaign, between 0.5 and $1.1 \mathrm{~g} / \mathrm{l}$ with an average of 0.8 $\mathrm{g} / \mathrm{l}$ for the 2015 samples, between 0.6 to $1.2 \mathrm{~g} / \mathrm{l}$ with an average of $0.9 \mathrm{~g} / \mathrm{l}$ for the points of the 2017 campaign, between 0.4 and $1.1 \mathrm{~g} / \mathrm{l}$ with an average of $0.8 \mathrm{~g} / \mathrm{l}$ for the 2018 campaign and between 0.4 to $1.3 \mathrm{~g} / \mathrm{l}$ with an average of $0.8 \mathrm{~g} / \mathrm{l}$ for the 2019 samples. The spatial-temporal distribution of the salinity of the Hauterivian aquifer shows a slight dilution of the waters analyzed in 2015, 2017, 2018 and 2019 compared to those representing the 1997 campaign. This could be explained by the installation of the Igouzoullene dam (in 2004) in upstream favoring the recharge of this aquifer.

As the study area is under a semi-arid climate, with a tendency towards an arid climate in recent years accompanied by a decrease in precipitation and an increase in the temperature, which frequently causes intense periods of drought resulting in evaporation that affects surface and groundwater, especially the shallow waters, the degradation of the groundwater quality is mainly due to this situation and the decrease in the piezometric level caused by climate change.

\section{Isotopy}

The isotopic approach is of crucial importance in studies of aquifer systems. They make it possible to determine the groundwater origin and their residence times, to identify and quantify the rate of mixing between two types of water and to locate the recharge areas (Fontes 1976).

For the upstream part (Cenomanian-Turonian aquifer), the oxygen-18 contents vary between a minimum of $-6 \%$ vs SMOW and a maximum of $-3.3 \%$ vs SMOW, with an average of $-4.9 \%$ o vs SMOW. For deuterium, the maximum value is $-20.2 \%$ vs SMOW and the minimum value equal to $-34.5 \%$ vs SMOW with an average of $-28.4 \%$ vs SMOW (Appendix 2). As for the downstream part, the contents of 
oxygen-18 vary between a minimum of $-5 \%$ vs SMOW and a maximum of -1.8 \%o vs SMOW, with an average of -3.9 \%o vs SMOW for the Plio-Quaternary aquifer and between a minimum of $-5 \%$ vs SMOW and a maximum of $-4.4 \%$ vs SMOW, with an average of $-4.7 \%$ vs SMOW for the Turonian aquifer. For deuterium contents, the maximum value is $-8.9 \%$ vs SMOW and the minimum value equal to -29.7 \%o vs SMOW with an average value of -22.6 \%o vs SMOW for the Plio-Quaternary layer. As for the Turonian, the maximum value is $-27.3 \%$ vs SMOW and the minimum value equal to $-28.5 \%$ vs SMOW with an average value of $-27.9 \%$ vs SMOW (Appendix 2). The comparison of the stable isotope contents of the upstream part and the downstream part of the Essaouira basin shows a slight depletion of the waters of the upstream part compared to those of the downstream part in these isotopes. This is due to the effect of elevation and continentality due to the remoteness of the coast.

In the absence of a local meteorological line characterizing the isotopic composition of the rainwater in the study area, the meteoric line with equation $\delta^{2} \mathrm{H}=7.95 \times \delta^{18} \mathrm{O}+11.3$ was considered by Mennani et al. (2001) as an input function for the aquifer systems of the Essaouira basin. Figure 18, representing the variation of $\delta^{2} \mathrm{H} v s . \delta^{18} \mathrm{O}$ of the groundwater representing the Cenomanian-Turonian aquifer, shows that some samples are located above the global meteoric water line (GMWL) and around the local meteoric water line (LMWL). This reflects that the aquifer recharge is ensured by the infiltration of precipitation of oceanic origin without significant evaporation. While some points are located below GMWL suggesting that these points have evaporated before being infiltrated to the aquifer. The sample of precipitation is an annual average of samples collected in 2004, 2006, 2016 and 2018. As for the seawater sample, we refer to values obtained by Carreira et al. 2014.

The distribution of representative samples of the groundwater representing the Plio-Quaternary and Turonian aquifers (downstream part) on the correlation diagram $\delta^{2} \mathrm{H}$ vs $\delta^{18} \mathrm{O}$ (Fig.18) shows that the majority of the points are scattered around the GMWL and LMWL reflecting a recharge by infiltration of oceanic rainwater (Group1). This supply of the shallow aquifer by rainwater, which is at the origin of the reduction in the salinity of the waters in these wells, is in perfect agreement with the hydrogeochemical data, in particular, well 27/51 which has low salinity. This well is the closest to the freshwater pole. Other local recharge points for rainwater have been identified in the bowl of the Essaouira basin (example 06, 15/51). This recharge is probably favored by the lithological nature and the small thickness of the unsaturated zone. This group contains both the majority of the samples representing the shallow PlioQuaternary aquifer and all the water points representing the deep Turonian aquifer. This suggests the existence of a connection between these two aquifer systems.

Other water points are distinguished by their position below the GMWL (Group 2), they line up along a line with a slope less than 8 characteristics of evaporation phenomenon. This last process mainly concerns surface waters (098 and 099) and wells 105/51 and 327/51 located respectively in the northeast and south part of the aquifer (Fig.18). Evaporation can probably take place before water infiltration, in the unsaturated zone or during sampling. In the same diagram, well 11/51 is aligned on the freshwaterseawater mixture line. This confirms that the increase in mineralization in this well is caused by the phenomenon of marine intrusion.

Page $14 / 41$ 
Following the availability of Tritium data, only the Cenomanian-Turonian aquifer was the subject of the groundwater dating in the study area. However, the tritium contents vary between 0 and 2.1TU. The highest values were recorded in the Et Tleta Hanchane region and the Kourimat region. This confirms that the recharge of the aquifer through rainwater is low and limited to a few regions (Fig.19). According to Mazor (1991), a tritium content greater than 1 TU indicates a post-nuclear recharge and content less than $1 \mathrm{TU}$ represents a pre-nuclear recharge or a mixture between recent and old waters. The high tritium levels have been observed in the Kourimat and Et Tleta Hanchane region (recharge zone), and they can be attributed to the recent infiltration of precipitation.

The projection of the samples from the two 2016 and 2007 campaigns (Fig.19) shows that certain points are located above the line $1 \mathrm{TU}$ reflecting a recent recharge of the Cenomanian-Turonian aquifer, while the other points are located above below this line confirming a pre-nuclear recharge. A comparison of the ${ }^{3} \mathrm{H}$ content of the same water point sampled in 2007 and 2016 shows a decrease in the ${ }^{3} \mathrm{H}$ content. This decrease could be explained by the low recharge rate caused by the decrease in the precipitation rate, which the study sector has experienced in recent decades under the effect of climate change.

To get an idea on the evolution of ${ }^{18} \mathrm{O}$ contents of groundwater in the context of climate change, we have based on the two Plio-Quaternary and Turonian aquifers where we have monitoring of the isotopic signature. The results are grouped in Figure 20. The correlation diagram ${ }^{18} \mathrm{O}-{ }^{2} \mathrm{H}$ for each point during the 23-year (1995-2018) shows that the recharge of the Plio-Quaternary and Turonian aquifers is ensured by precipitation of oceanic origin without notable evaporation. Only two points are located below the GMWL, it is point 272/51 (in 2004) and point 11/51 (in 2018). This situation could be explained by the fact that point 272/51 underwent evaporation before infiltration, while point 11/51 underwent marine contamination as shown in Figure 21 where the electrical conductivity is around $10 \mathrm{mS} / \mathrm{cm}$. According to Figure 21 we see that the increase in electrical conductivity (salinity) is accompanied by a very small increase in the 18-oxygen contents. This slight enrichment in ${ }^{18} \mathrm{O}$ (1 to $1.5 \%$ ), may be due to the effect of evaporation caused by the increase in air temperature under the effect of climate change. This suggests that the isotopic content of the study area is impacted by climatic variations and therefore it can be concluded that global warming has an effect on the isotopic signature of groundwater within the Essaouira basin.

\section{Conclusion}

The water resource within the Essaouira basin is limited and unevenly distributed in space and time. This problem could limit water supply, which will be aggravated by the depletion of this resource due to the climate change impact which has become an ambiguous reality and whose effects on the environment are already visible.

The combination of hydroclimatic, piezometric, hydrogeochemical and isotopic approaches in the study of the groundwater resource within the Essaouira basin led to the following conclusions: 
The analysis results of the annual precipitation time series using the statistical tests, in particular, that of Pettitt and that of Mann-Kendall, made it possible to detect a decrease in precipitation in the whole basin of 12 to $16 \%$. This decrease in precipitation is accompanied by an increase in temperatures with a significant extent of warming of $2.3^{\circ} \mathrm{C}$. Based on the Gaussen diagram, the comparison of the duration of the dry period for the two periods 1987-2000 and 2001-2014 shows an extension of one month. This will no doubt have a negative effect on the groundwater recharge.

The piezometric approach has shown that the Cenomanian-Turonian, Plio-Quaternary, Barremian-Aptian and Hauterivian aquifers have retained the general direction of flow of their groundwater, during the study period. Monitoring the piezometry over a period of 24 years (1995-2019) for the Cenomanian-Turonian aquifer, 29 years (1990-2019) for the Plio-Quaternary aquifer and 43 years (1976-2019) for the aquifers Barremian-Aptian and Hauterivian shows a continuous drop in the piezometric level which exceeds $12 \mathrm{~m}$ for the Cenomanian-Turonian aquifer, $17 \mathrm{~m}$ for the Plio-Quaternary aquifer, around $8 \mathrm{~m}$ for the BarremianAptian aquifer and $5 \mathrm{~m}$ for the Hauterivian.

The general decline in the piezometric level could be explained by the decrease in precipitation following the harmful effect of climate change. This drawdown would probably cause a qualitative degradation of groundwater.

The hydrogeochemical study showed that the groundwater of the Cenomanian-Turonian aquifer presents the $\mathrm{Cl}-\mathrm{Ca}-\mathrm{Mg}, \mathrm{Cl}-\mathrm{Ca}, \mathrm{Cl}-\mathrm{Na}$, and $\mathrm{HCO}_{3}-\mathrm{Ca}$ mix facies with the dominance of the $\mathrm{Cl}-\mathrm{Ca}-\mathrm{Mg}$ mix facies, and $\mathrm{Cl}-\mathrm{Ca}$. The study of the temporal evolution of these facies shows that there has been no remarkable change. The groundwater of the Plio-Quaternary and Turonian aquifers are of mixed type between $\mathrm{Cl}-\mathrm{Na}$ and $\mathrm{Cl}-\mathrm{Ca}-\mathrm{Mg}$. The chemical facies experienced a slight evolution from the $\mathrm{Cl}-\mathrm{Na}$ facies to the $\mathrm{Cl}-\mathrm{Na}$ and $\mathrm{Cl}-\mathrm{Ca}-\mathrm{Mg}$ facies for the Plio-Quaternary aquifer and from the $\mathrm{Cl}-\mathrm{Na}$ facies to the $\mathrm{Cl}-\mathrm{Ca}-\mathrm{Mg}$ facies for the Turonian aquifer. As for the Barremian-Aptian and Hauterivian aquifers, they generally have three types of chemical facies: $\mathrm{Cl}-\mathrm{Na}, \mathrm{Cl}-\mathrm{Ca}-\mathrm{Mg}$, and $\mathrm{HCO}_{3}-\mathrm{Ca}-\mathrm{Mg}$, with the dominance of the $\mathrm{Cl}-\mathrm{Ca}-\mathrm{Mg}$ facies. For the study period, a remarkable evolution of the facies was observed; from the $\mathrm{Cl}-\mathrm{Na}$ facies to the $\mathrm{Cl}-\mathrm{Ca}-\mathrm{Mg}$ facies.

Examination of the correlations established between the concentrations of major elements has shown that the mineralization of groundwater is controlled by the phenomenon of the dissolution of the evaporitic minerals (halite, gypsum and/or anhydrites) and carbonates (dolomite), by the reverse ion exchange phenomenon and by the marine intrusion, especially at the Plio-Quaternary aquifer. The study of the spatio-temporal evolution of the groundwater quality in the study area shows a gradual deterioration in time and space.

The tracing of the groundwater in the Essaouira basin by stable isotopes has shown that the groundwater recharge in the upstream part of the basin studied is ensured by precipitation of Atlantic origin without significant evaporation. The same method of recharging is marked at the downstream part, with this time the presence of contamination by seawater. 
Tritium tracing based on the same wells sampled in 2007 and 2016 shows a significant decrease that reaches $2 \mathrm{TU}$ in certain wells. This trend could be explained by the low recharge rate following the decrease in the precipitation rate experienced by the study area in recent years. The temporal evolution of the ${ }^{18} \mathrm{O}$ contents generally shows slight enrichment of 1 to $1.5 \%$, this may be due to the effect of evaporation caused by the increase in air temperature under the effect of climate change.

However, the Essaouira basin is more vulnerable to climate change because its recharge is entirely dependent on meteoric waters.

\section{Declarations}

\section{Availability of data and materials}

Please contact author for data requests

\section{Funding}

No funding was received

\section{Competing interests}

The authors declare that they have no competing interests.

\section{Authors' contributions}

$\mathrm{MB}$ and SO prepare figures and maps and analyzed the data, DO helped in the interpretation. NE collaborated with the corresponding author in the construction and submission of manuscript. All authors read and approved the final manuscript.

\section{Acknowledgements}

The authors are grateful to the Editor-in-Chief and the Editorial Office of "Progress in Earth and Planetary Science Journal", who handled this manuscript, and to the anonymous reviewers who greatly improved an early version of the manuscript. Also the authors would like to express their thanks to the staff members of Laboratory of Radio-Analyses and Environment (LRAE) (Sfax, Tunisia) and the one of Nuclear Technology Institute in Lisbon (Portugal).

\section{References}

Abutaleb KAA, Mohammed AHE, Ahmed MHM (2018) Climate change impacts, vulnerabilities and adaption measures for Egypt's Nile Delta. Earth Syst Environ 2:183-192.

Al-Maktoumi A, Zekri S, El-Rawy M, Abdalla O, Al-Wardy M, Al-Rawas R, Charabi Y (2018) Assessment of the impact of climate change on coastal aquifers in Oman. Arab J Geosci 11: 501. DOI:10.1007/s12517- 
018-3858-y.

Alpert P, Krichak SO, Shafir H, Haim D, Osetinsky I (2008) Climatic trends to extremes employing regional modeling and statistical interpretation over the E. Mediterranean. Glob Planet Change 63:163-170.

Amghar M (1989) Apports des méthodes d'analyses de la tectonique cassante à la connaissance de I'histoire alpine du Haute Atlas Occidental. L'exemple du versant nord du bloc ancien et de l'Atlas d'Agadir (Haut Atlas, Maroc). Thèse $3^{\text {ème }}$ cycle, Université Cadi Ayyad, Maroc.

Babqiqi A (2014) Changements climatiques au Maroc: Étude du cas de la région de Marrakech Tensift Al Haouz et implications sur l'agriculture à I'horizon 2030. Thèse de doctorat, Université Cadi Ayyad, Maroc.

Bagnouls F, Gaussen H (1953) Saison sèche et indice xérothermique. Bull Soc Hist Nat Toulouse. 88(34):193-239.

Bahir M, Mennani A, Jalal M, Fakir Y (2002) Impact de la sécheresse sur les potentialités hydriques de la nappe alimentant en eau potable la ville d'Essaouira (Mogador, Maroc). Sécheresse 13:13-9.

Bahir M, Ouhamdouch S, Carreira PM (2016) La ressource en eau au Maroc face aux changements climatiques; cas de la nappe Plio-Quaternaire du bassin synclinale d'Essaouira. Comun Geol 103:35-44.

Bahir M, Ouhamdouch S, Carreira PM (2018) Isotopic and geochemical methods for studying water-rock interaction and recharge mode: application to the Cenomanian-Turonian and Plio-Quaternary aquifers of Essaouira Basin, Morocco. Mar Freshwater Res 69:1290-1300.

Bahir M, Ouazar D, Ouhamdouch S (2019) Hydrogeochemical investigation and groundwater quality in Essaouira region, Morocco. Mar Freshwater Res 70:1317-1332.

Berhail S (2019) The impact of climate change on groundwater resources in northwestern Algeria. Arab J Geosci 12:770. DOI:10.1007/s12517-019-4776-3.

Capaccioni B, Didero M, Paletta C, Didero L (2005) Saline intrusion and refreshening in a multilayer coastal aquifer in the Catania Plain (Sicily, Southern Italy): dynamics of degradation processes according to hydrochemical characteristics of groundwaters. J Hydrol 307:1-16.

Carreira PM, Marques JM, Nunes D (2014) Source of groundwater salinity in coastline aquifers based on environmental isotopes (Portugal): Natural vs. human interference. A review and reinterpretation. Appl Geochem 41:163-175.

Carreira PM, Bahir M, Ouhamdouch S, Fernandes PG, Nunes D (2018) Tracing salinization processes in coastal aquifers using an isotopic and geochemical approach: comparative studies in western Morocco and southwest Portugal. Hydrogeol J 26:2595-2615. 
Chenaker H, Houha B, Valles V (2017) Isotope studies and chemical investigations of hot springs from North-Eastern Algeria. J Mater Environ Sci 8:4253-4263.

Daget $\mathrm{P}$ (1977) Le bioclimat mediterraneen: Caracteres generaux, modes de caracterisation. Vegetatio 34(1):1-20.

Dresh J (1962) Le Haut Atlas Occidental. Dans "Aspect de la géomorphologie du Maroc". Notes et Mémoire du Service Géologique-Maroc 96:107-121.

Driouech F (2010) Distribution des précipitations hivernales sur le Maroc dans le cadre d'un changement climatique: descente d'échelle et incertitudes. Thèse de doctorat, Université. Toulouse, France.

Duffaud F (1960) Contribution à l'étude stratigraphique du bassin secondaire du Haut Atlas Occidental (Sud-Ouest du Maroc). Bull Soc Géol Fr 7:728-734.

Duffaud F, Brun L, Planchot B (1966) Bassin du Sud-Ouest Marocain (SW Morocco Basin). In: Reyre (ed.) Bassin Sédimentaire du Littoral Africain, partie I, Paris, pp 5-12.

El Kharraz J, El-Sadekb A, Ghaffourc N, Mino E (2012). Water scarcity and drought in WANA countries. Procedia Eng 33:14-29.

Epstein S, Mayeda T (1953) Variation of ${ }^{18} \mathrm{O}$ content of waters from natural sources. Geochim Cosmochim Acta 4:213-224.

Fetter CW (1993) Contaminant Hydrogeology. Macmillan Publishing Company, New York.

Fontes JC (1976) Isotopes du milieu et cycle des eaux naturelles: quelques aspects. Thèse Doctorat d'Etat. Université de Paris VI, France.

Friedman I (1953) Deuterium content of natural waters and other substances. Geochim Cosmochim Acta 4:89-103.

GIEC (2007) Résumé à l'intention des décideurs. In: Bilan 2007 des changements climatiques: Les bases scientifiques physiques. Contribution du Groupe de travail I au quatrième Rapport d'évaluation du Groupe d'experts intergouvernemental sur l'évolution du climat. (Solomon, S, Qin D, Manning M, Chen Z, Marquis M, Averyt KB, Tignor M and Miller HL (eds)). Cambridge University Press, Cambridge, United Kingdom and New York, NY, USA.

Green TR, Makoto T, Henk K, Gurdak JJ, Allen DM, Hiscock KM, Holger T, Alice A (2011) Beneath the surface of global change: Impacts of climate change on groundwater. J Hydrol 405:532-560.

Hallouz F, Meddi M, Mahe G, Karahacane H, Rahmani SEA (2019) Tendance des précipitations et évolution des écoulements dans un cadre de changement climatique : bassin versant de l'oued Mina en Algérie. RSE 32(2):83-114. 
Hannachi A, Fenni M (2013) Etude floristique et écologique des mauvaises herbes des cultures de la région de Batna (Algérie). Revue Agriculture 5:24-36.

IPCC (2013) Climate Change 2013: The Physical Science Basis . Contribution of Working Group I to the Fifth Assessment Report of the Intergovernmental Panel on Climate Change (Stocker TF, Qin D, Plattner GK, Tignor M, Allen SK, Boschung J, Nauels A, Xia Y,Bex V and Midgley PM (eds)) Cambridge University Press, Cambridge, United Kingdom and New York, NY, USA.

Jalal M, Blavoux B, Bahir M, Bellion Y, Laftouhi N, Puig JM, Mennani A, Daniel M (2001) Etude du fonctionnement du système aquifère karstique cénomano-turonien de l'oued Igrounzar (Bassin d'Essaouira, Maroc). J Afr Earth Sci 32:803-817.

Kendall MG (1975) Multivariate nonparametric tests for trend in water quality. Water Resour Bull 24:505512.

Lachaal F, Chargui S, Messaoud RB, Chekirbane A, Tsujimura M, Mlayah A, Massuel S, Leduc C (2018) Impacts of global changes on groundwater resources in north-east Tunisia: The case of the Grombalia phreatic aquifer. In Calvache ML et al. (eds.), Groundwater and Global Change in the Western Mediterranean Area, Environmental Earth Sciences. Springer International Publishing Switzerland, 179188.

Lebel T, Vischel T (2005) Climat et cycle de l'eau en zone tropicale : un problème d'échelle. CR Geoscience, 337:29-38.

Lucas LL, Unterweger MP (2000) Comprehensive review and critical evaluation of the half-life of tritium. Journal of Research of NIST 105:541-549.

Mann HB (1945) Nonparametric tests against trend, Econometrical 13:245-259.

Marfia AM, Krishnamurthy RV, Atekwana EA, Panton WF (2004) Isotopic and geochemical evolution of ground and surface waters in a karst dominated geological setting:a case study from Belize, Central America. Appl Geochem 19:937-946.

Mazor E (1991) Applied chemical and isotopic groundwater hydrology. Buckingham: Open University Press.

Mennani A (2001) Apport de l'hydrochimie et de l'isotopie à la connaissance du fonctionnement des aquifères de la zone côtière d'Essaouira (Maroc Occidental). Thèse de doctorat, Université Cadi Ayyad, Maroc.

Mennani A, Blavoux B, Bahir M, Bellion Y, Jalal M, Daniel M (2001) Apports des analyses chimiques et isotopiques à la connaissance du fonctionnement des aquifères plio-quaternaire et turonien de la zone synclinale d囚Essaouira (Maroc occidental). J Afr Earth Sci 32:819-835. 
Misra AK (2014) Climate change and challenges of water and food security. Int J Sustain Built Environ 3:153-165.

Ouhamdouch S, Bahir M, Souhel A, Carreira PM (2016) Vulnerability and impact of climate change processes on water resource in semi-arid areas: In Essaouira Basin (Morocco). In Grammelis P (ed.), Energy, Transportation and Global Warming, Green Energy and Technology. Springer International Publishing Switzerland, 719-736.

Ouhamdouch S, Bahir M, Carreira P (2018) Impact du changement climatique sur la ressource en eau en milieu semi-aride: exemple du bassin d'Essaouira (Maroc). Rev Des Sci De L'Eau 31:13-27.

Ouhamdouch S, Bahir M, Ouazar D, Goumih A, Zouari K (2020) Assessment of the climate change impact on the future evapotranspiration and flows from a semi-arid environment. Arab J Geosci (2020) 13:82. DOI:10.1007/s12517-020-5065-x.

Parkhurst DL, Appelo CAJ 1(999) User's guide to PHREEQC (version 2) -A computer program for speciation, batch-reaction, one-dimensional transport, and inverse geochemical calculations. USGS Water-Resour. Invest. Rep. 99-4259, 312 pp.

Pettitt AN (1979) A non-parametric approach to the change-point problem. Appl Stat 28:126-135.

Piper AM (1944) A graphic procedure in the geochemical interpretation of water analyses. Trans Am Geophys Union 25:914-923.

Ragab R, Prudhomme C (2002) Climate change and water resources management in arid and semi-arid regions: Prospective and challenges for the 21st Century. Biosystems Eng 81:3-34.

Rodier J, Legube B, Merlet N, Mialocq JC, Leroy P, Houssin M, Lavison G, Bechemin C, Vincent M, Rebouillon P, Moulin L, Chomodé P, Dujardin P, Gosselin S, Seux R, Al Mardini F (2009) L'Analyse de l'eau. 9 e édition, Dunod, Paris.

Sinan M, Boussetta M, El Rherari A (2009) Changements climatiques: causes et conséquences sur le climat et les ressources en eau. Revue HTE 142:21-30.

Stour L and Agoumi A (2008) Sécheresse climatique au Maroc durant les dernières décennies. Hydroécol Appl 16:215-232.

Vicente-Serrano SM (2006): Spatial and temporal analysis of droughts in the Iberian Peninsula (19102000). Hydrolog Sci J 51:83 -97.

WHO (2011) Guidelines for drinking water quality, fourth edition. Geneva.

Xu ZX, Chen YN, Li JY (2004) Impact of climate change on water resources in the Tarim River Basin. Water Resour Manag 18:439-458. 


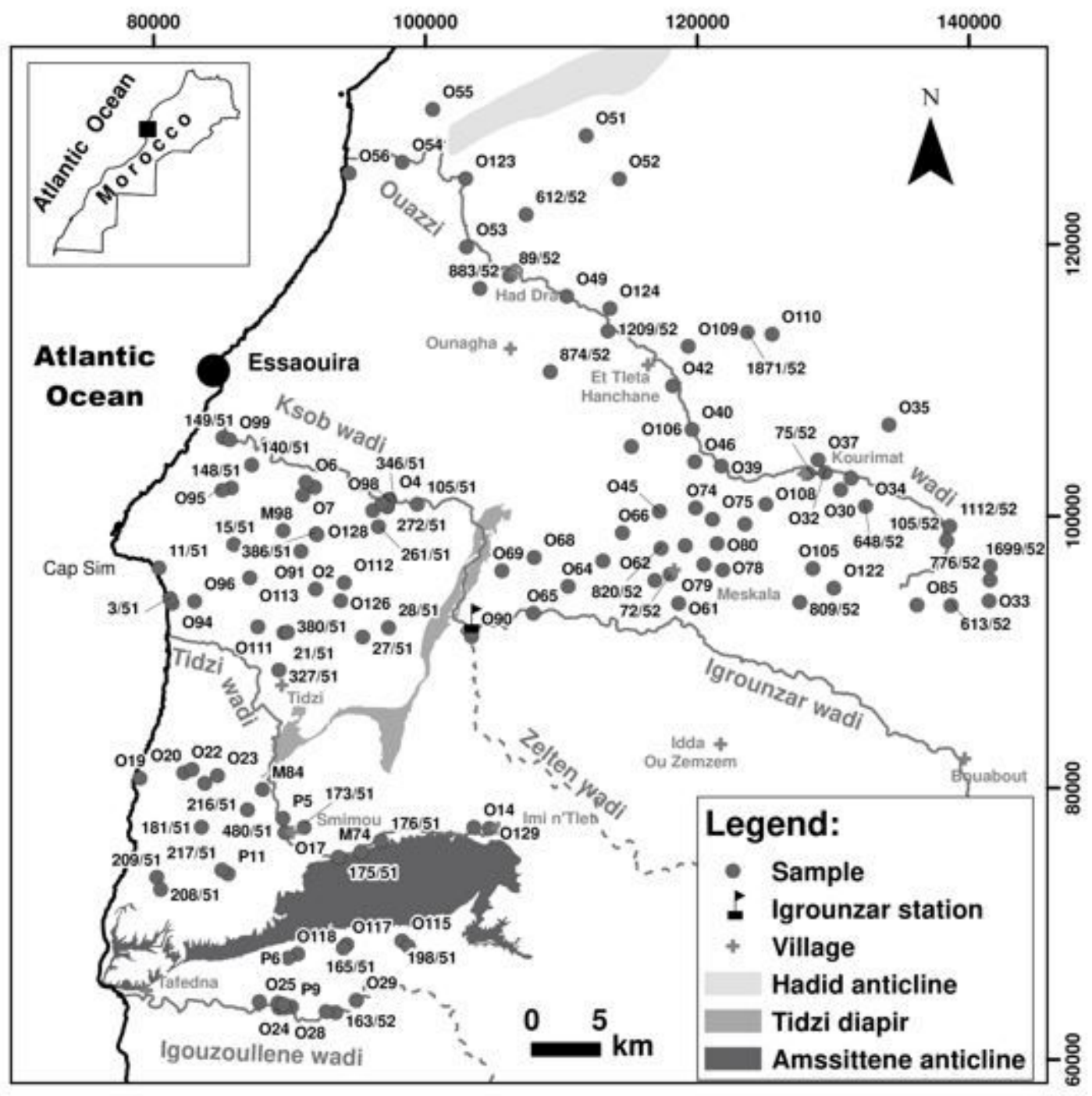

Figure 1

Location of study area 


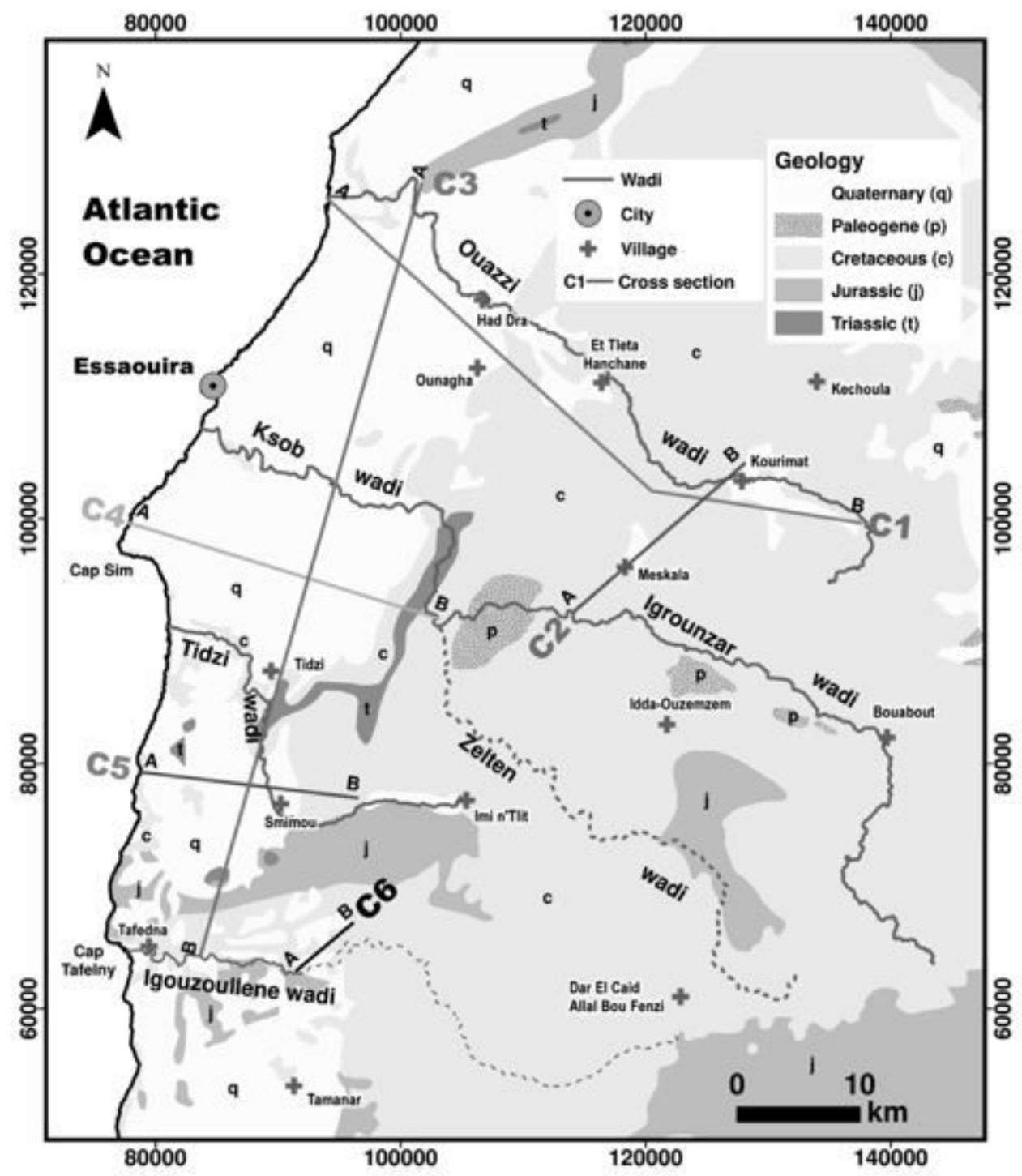

Figure 2

Geological map of study area and cross sections location 
A

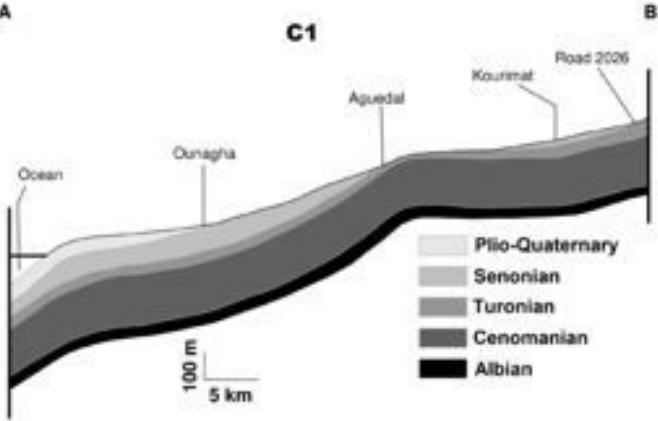

A
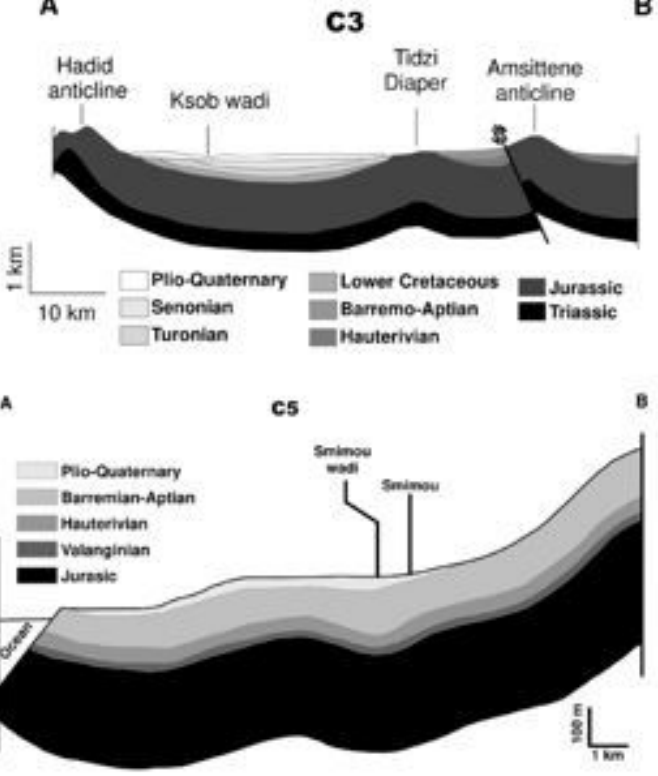

A C2 Kouvinat B

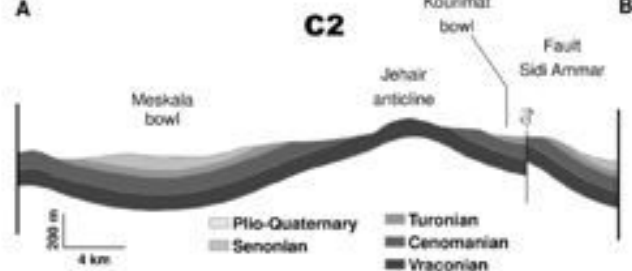

B

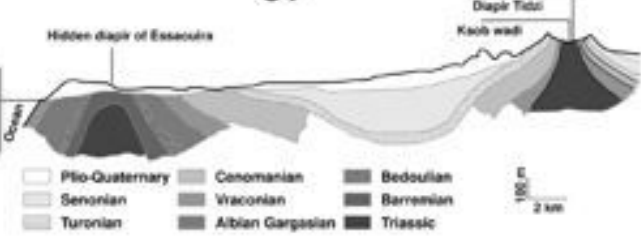

A

c6

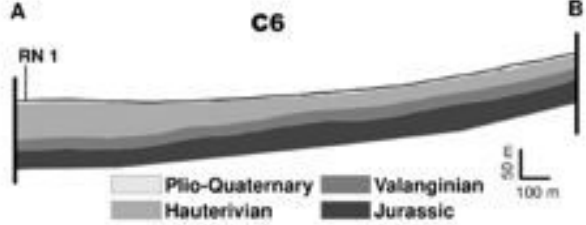

Figure 3

cross sections (cf Figure 2) 

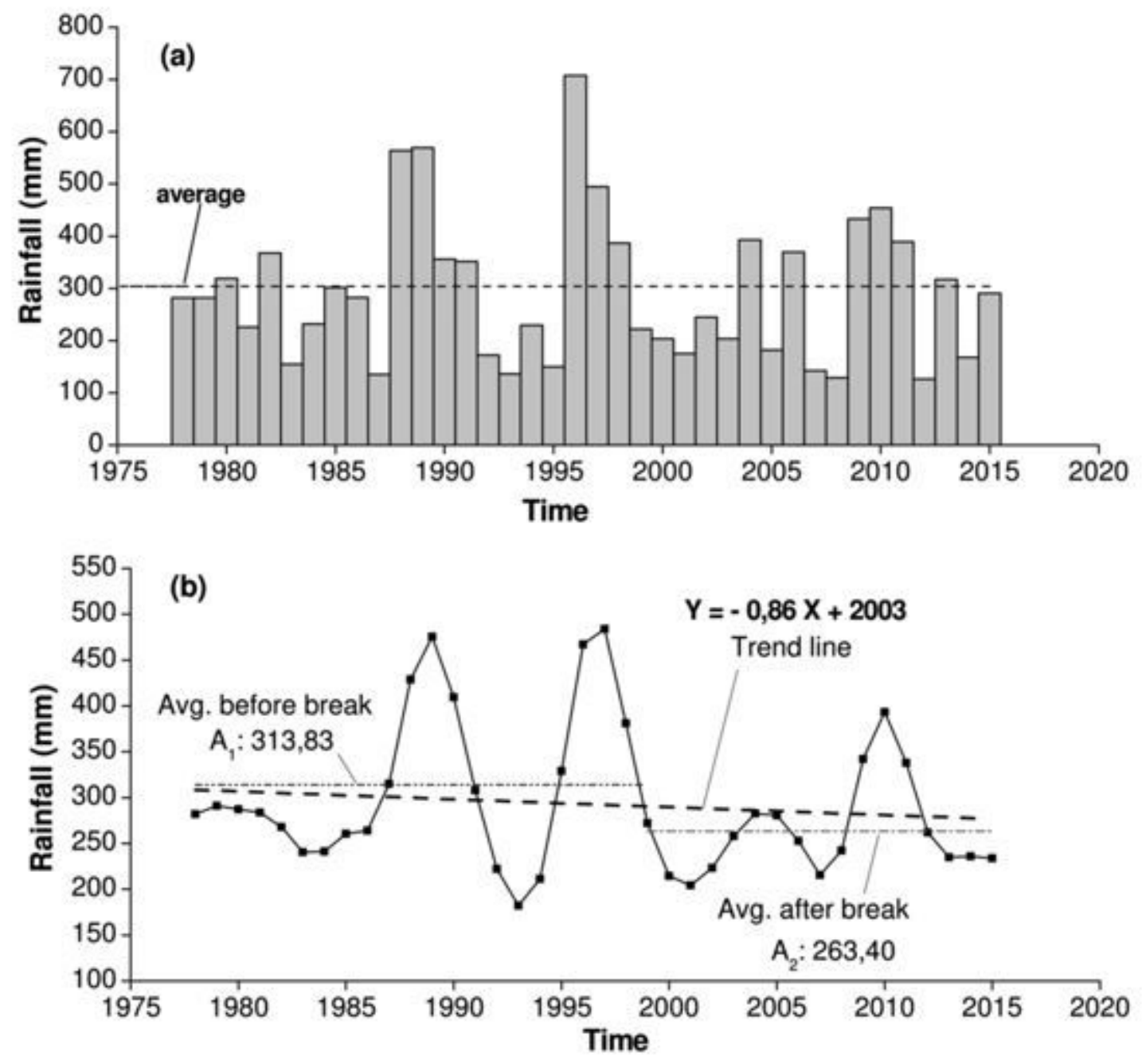

Figure 4

(a) Annual precipitations (b) Pettitt test result 

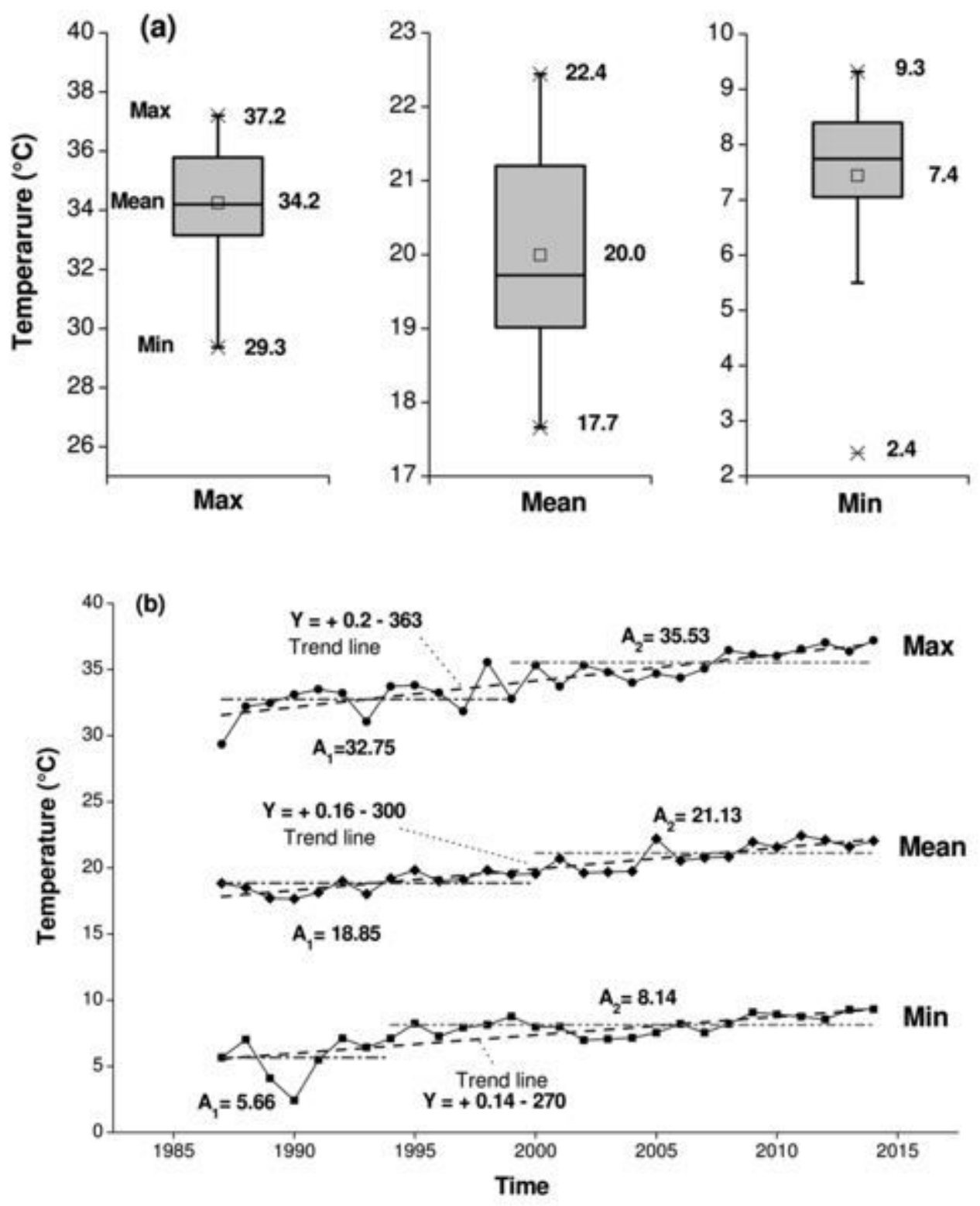

Figure 5

(a) Maximum, average and minimum temperatures, (b) Pettitt test results
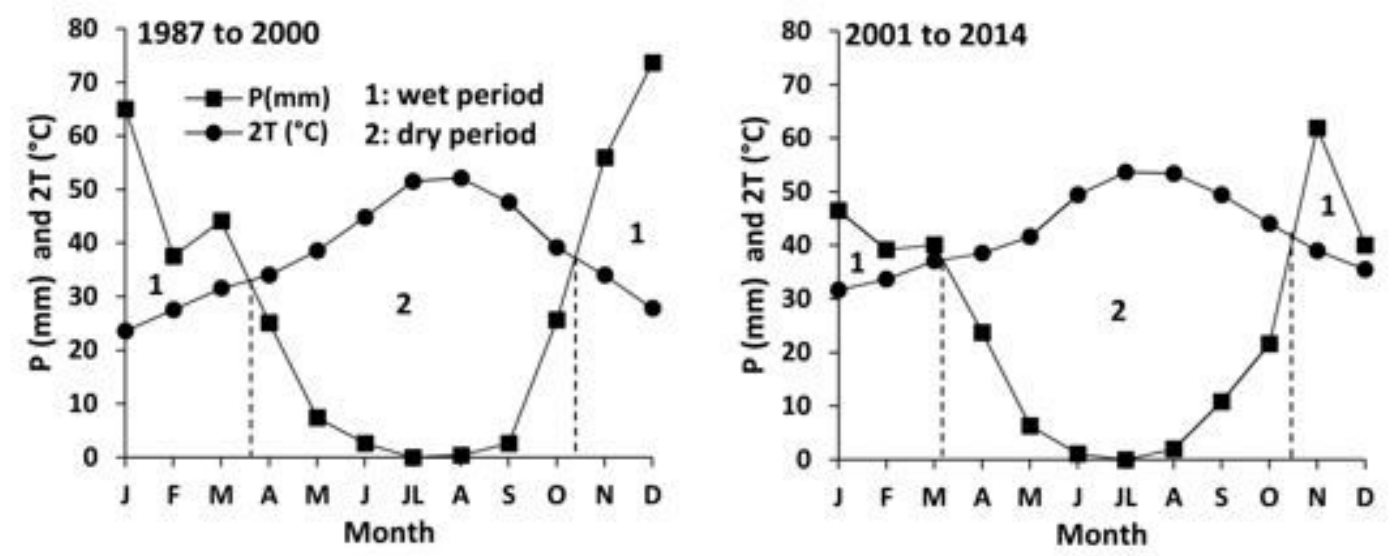
Figure 6

Gaussen diagram
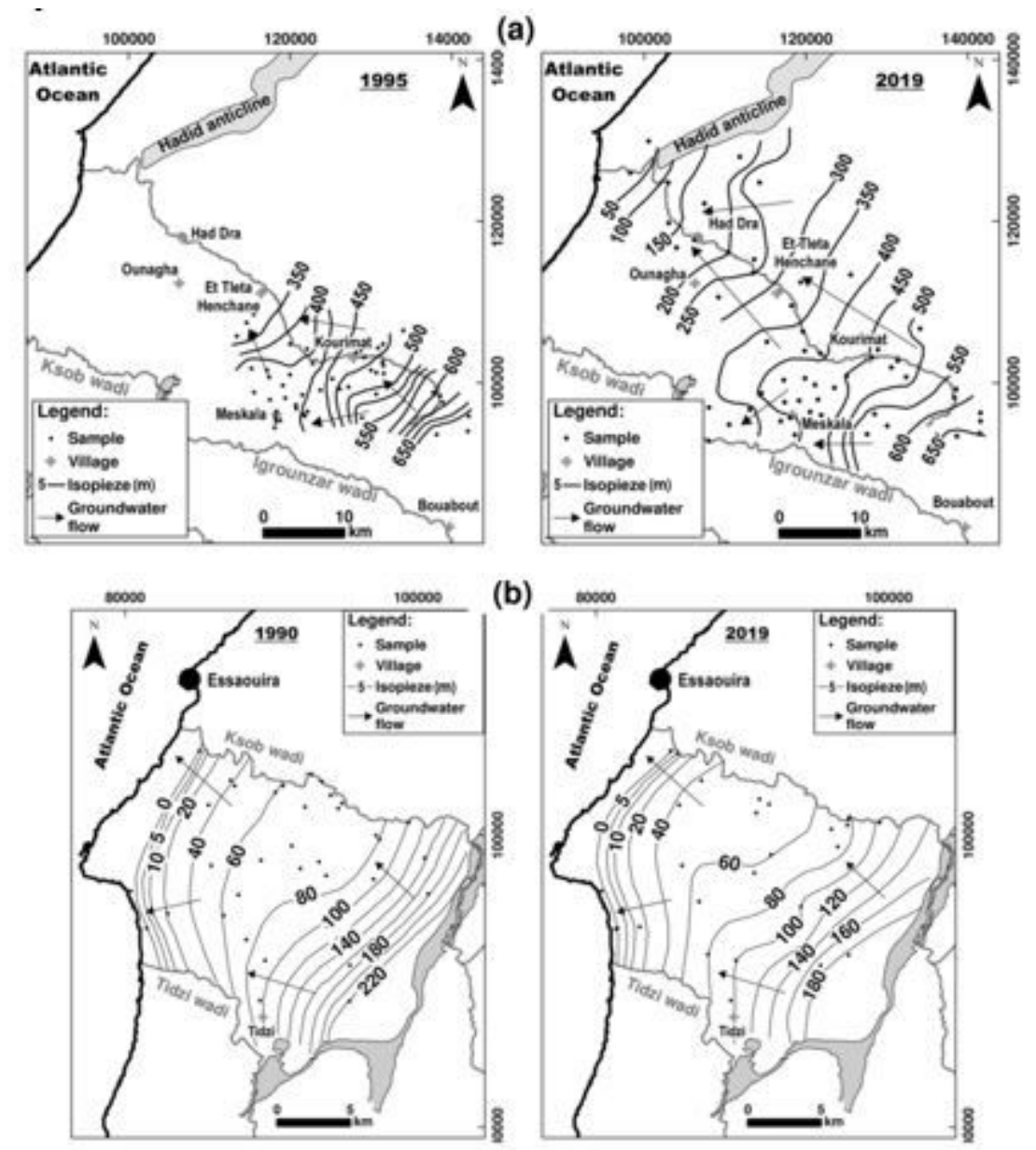

(b)
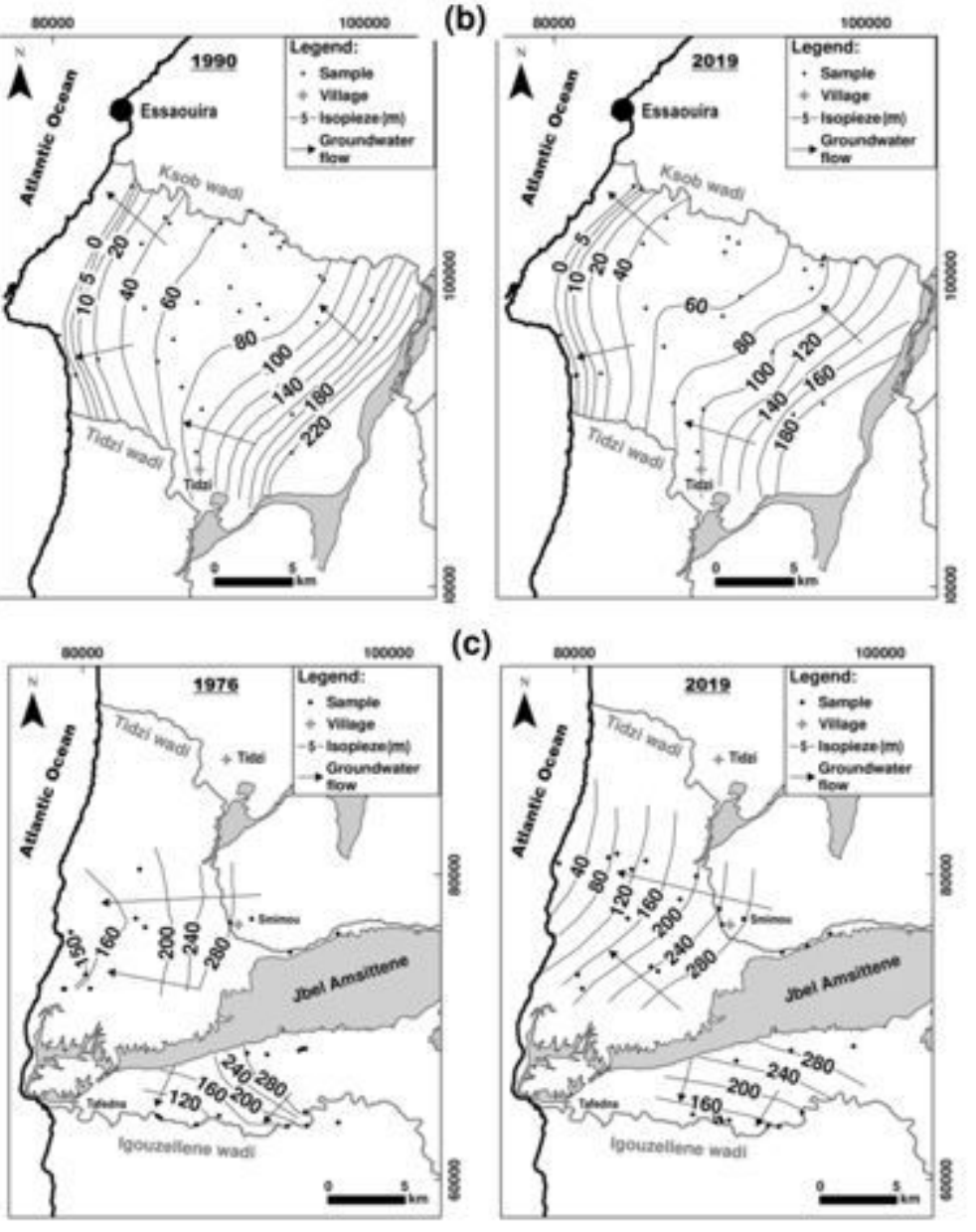

(c)

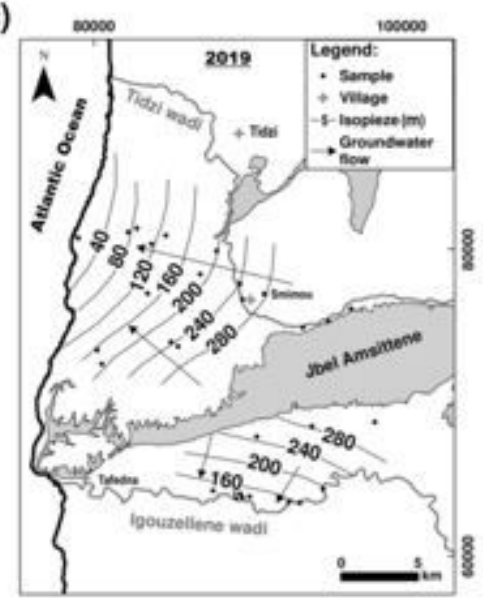

Figure 7

Piezometric maps of the aquifer (a) Cenomanian-Turonian (b) Plio-Quaternary and (c) Barremian-Aptian and Hauterivian 

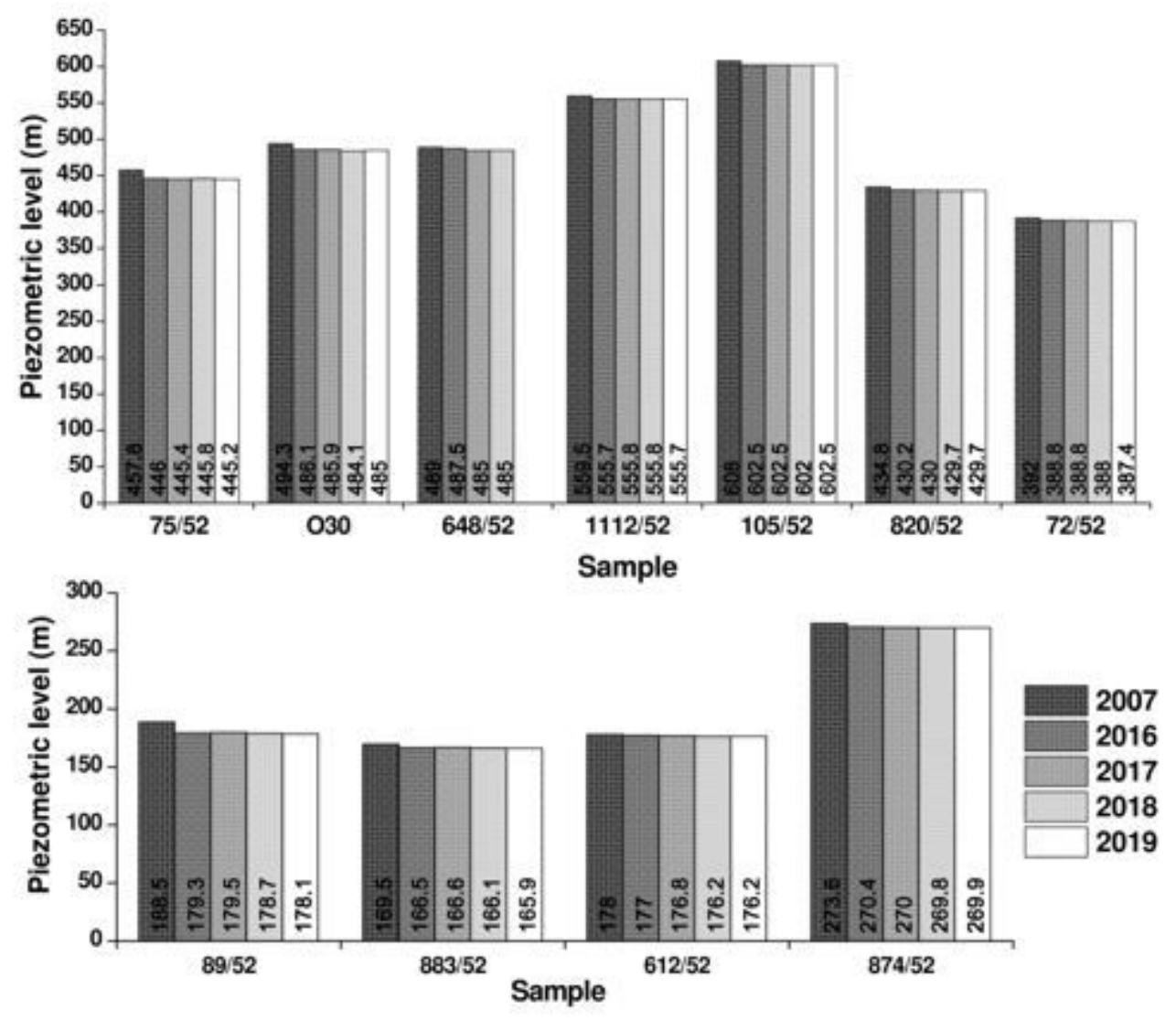

Figure 8

Temporal evolution of the piezometric level of certain wells capturing the Cenomanian-Turonian aquifer 

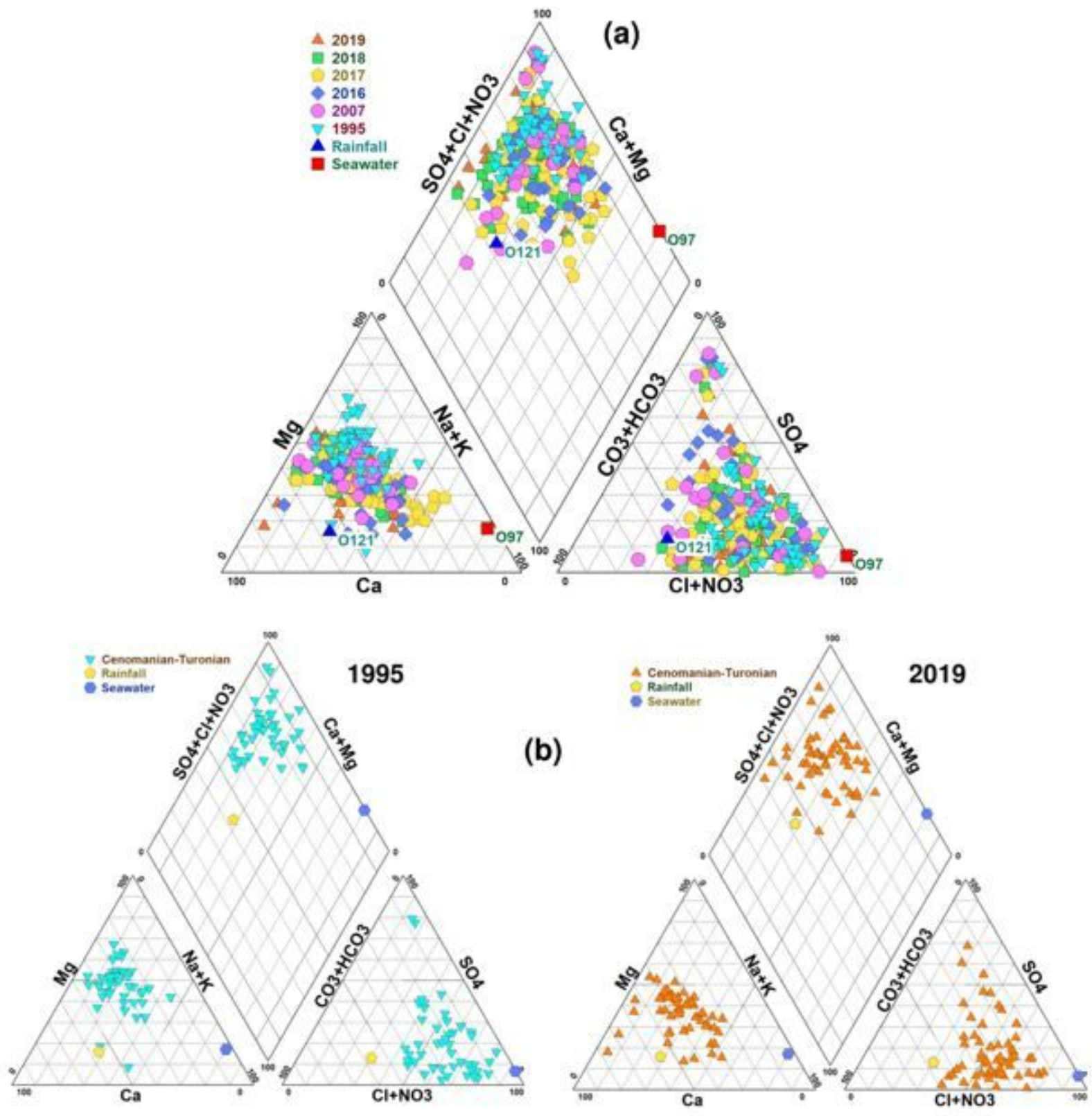

\section{Figure 9}

Piper Diagram of analysed samples of (a) Cenomanian-Turonian aquifer from 1995 to 2019 and (b) comparison between samples of 1995 and 2019 

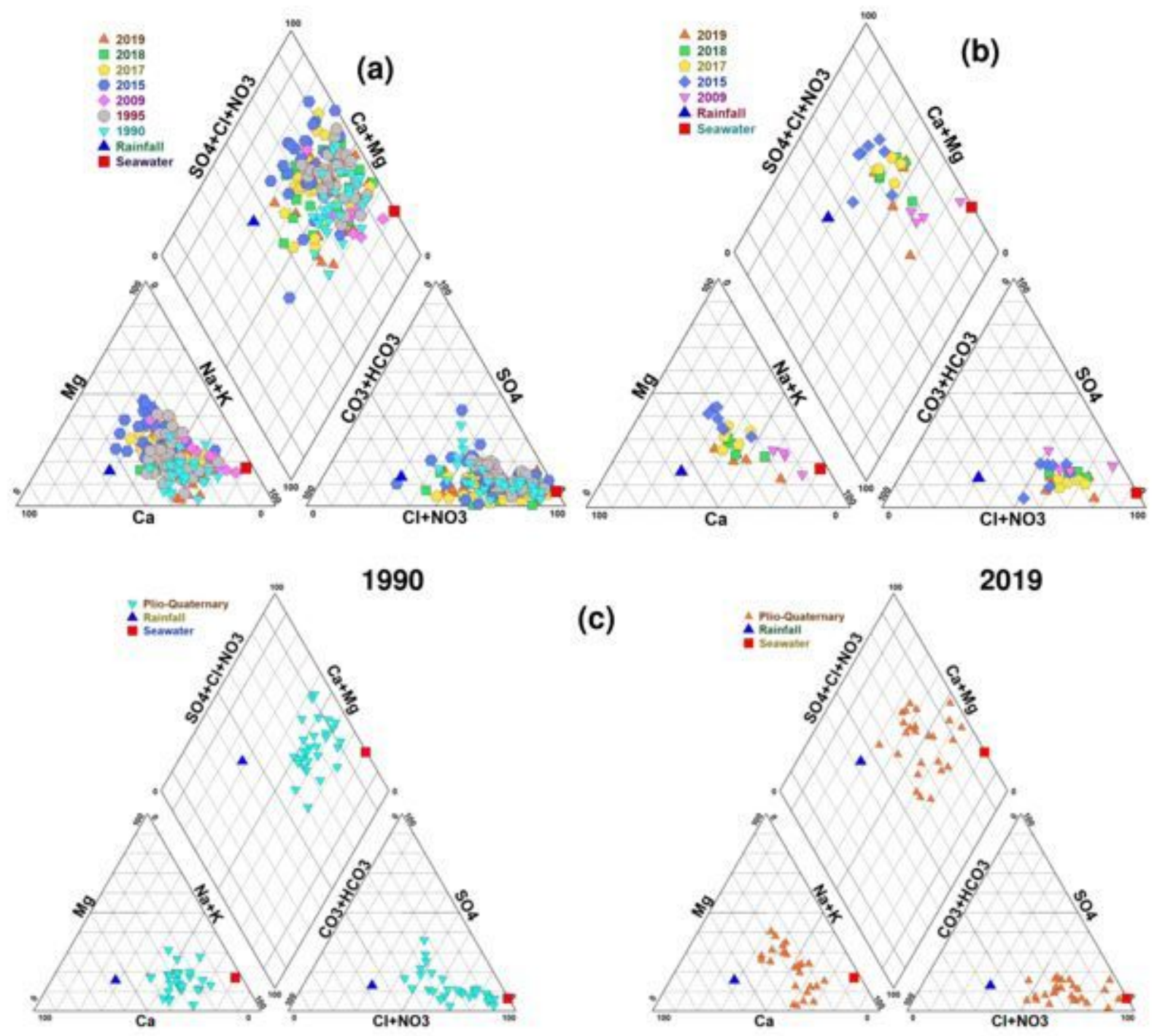

Figure 10

Piper Diagram of analysed samples of (a) Plio-Quaternary from 1990 to 2019 and of (b) Turonian from 2009 to 2019, and (c) comparison between samples of 1990 and 2019 for the Plio-Quaternary aquifer 

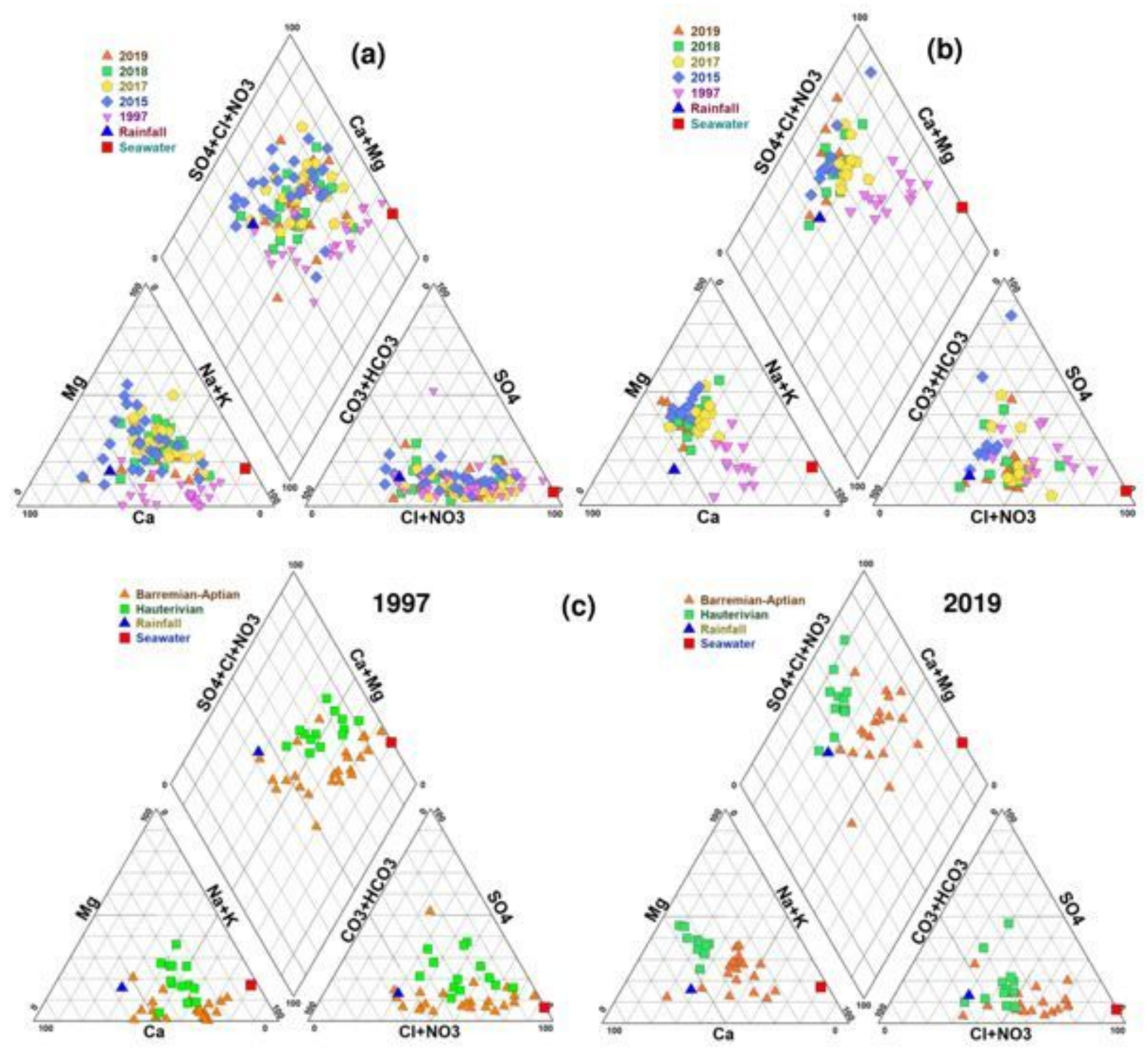

Figure 11

Piper Diagram of analysed samples of (a) Barremian-Aptian and (b) Hauterivian aquifers from 1997 to 2019, and (c) comparison between samples of 1997 and 2019 for the two aquifers 

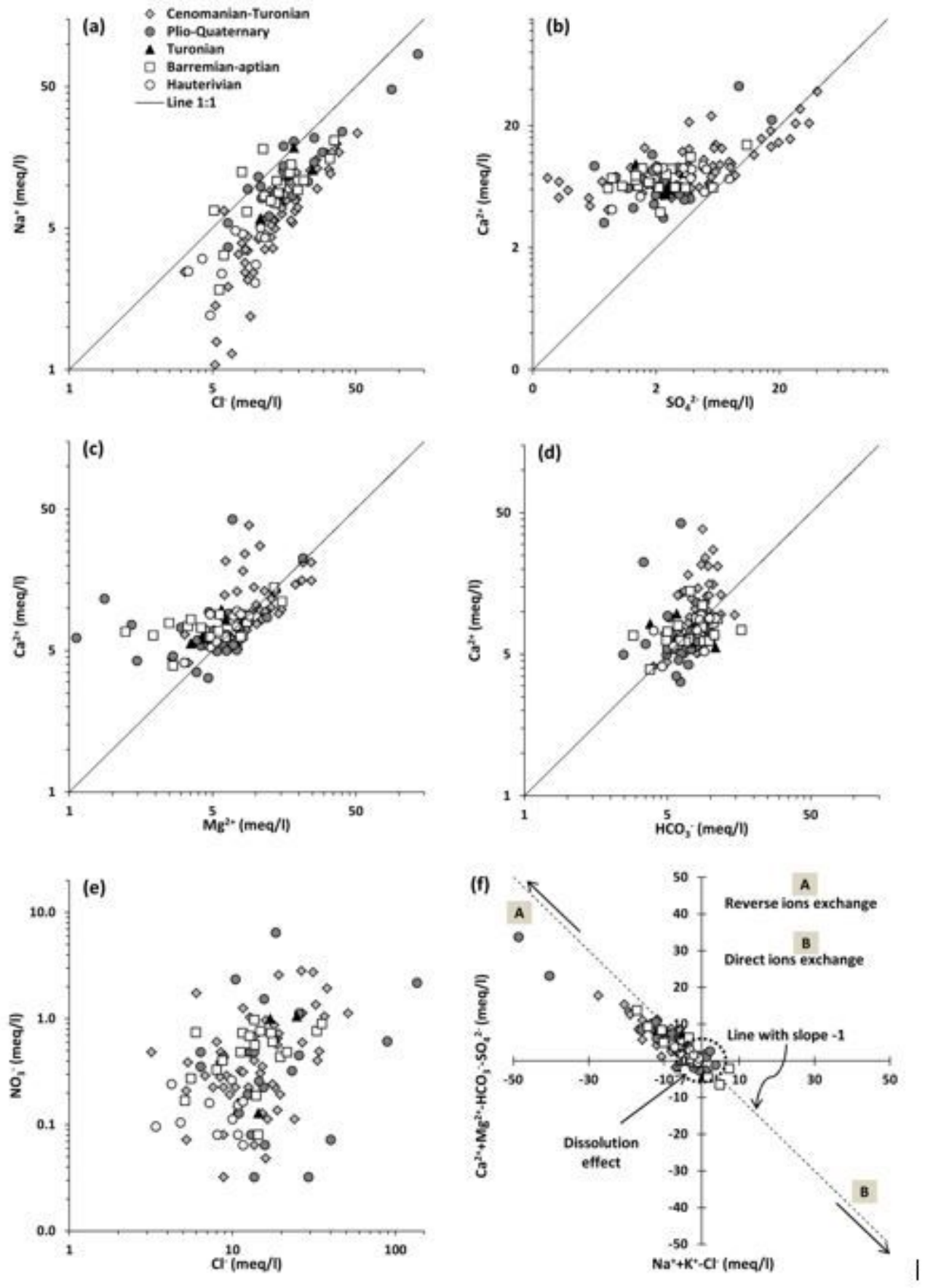

Figure 12

Correlation diagram (a) Na vs $\mathrm{Cl}$, (b) Ca vs $\mathrm{SO} 4$, (c) Ca vs $\mathrm{Mg}$, (d) $\mathrm{Ca}$ vs $\mathrm{HCO}$, (e) NO3- vs $\mathrm{Cl}$, and (f) (Ca+Mg-HCO3-SO4) vs ( $\mathrm{Na}+\mathrm{K}-\mathrm{Cl})$ 

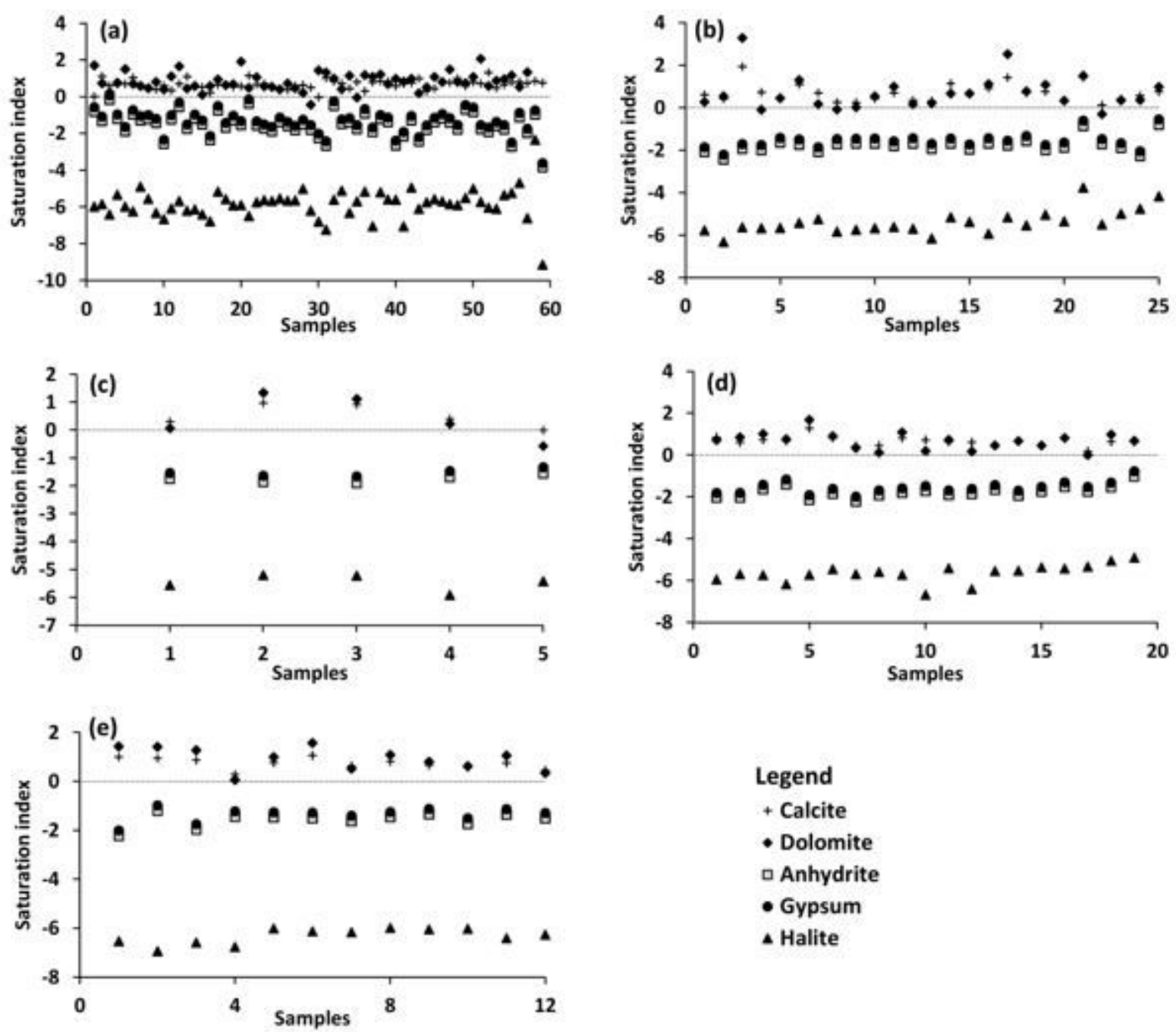

Figure 13

Saturation indices of analysed samples of (a) Cenomanian-Turonian, (b) Plio-Quaternary, (c) Turonian, (d) Barremian-Aptian, and (e) Hauterivian aquifers 


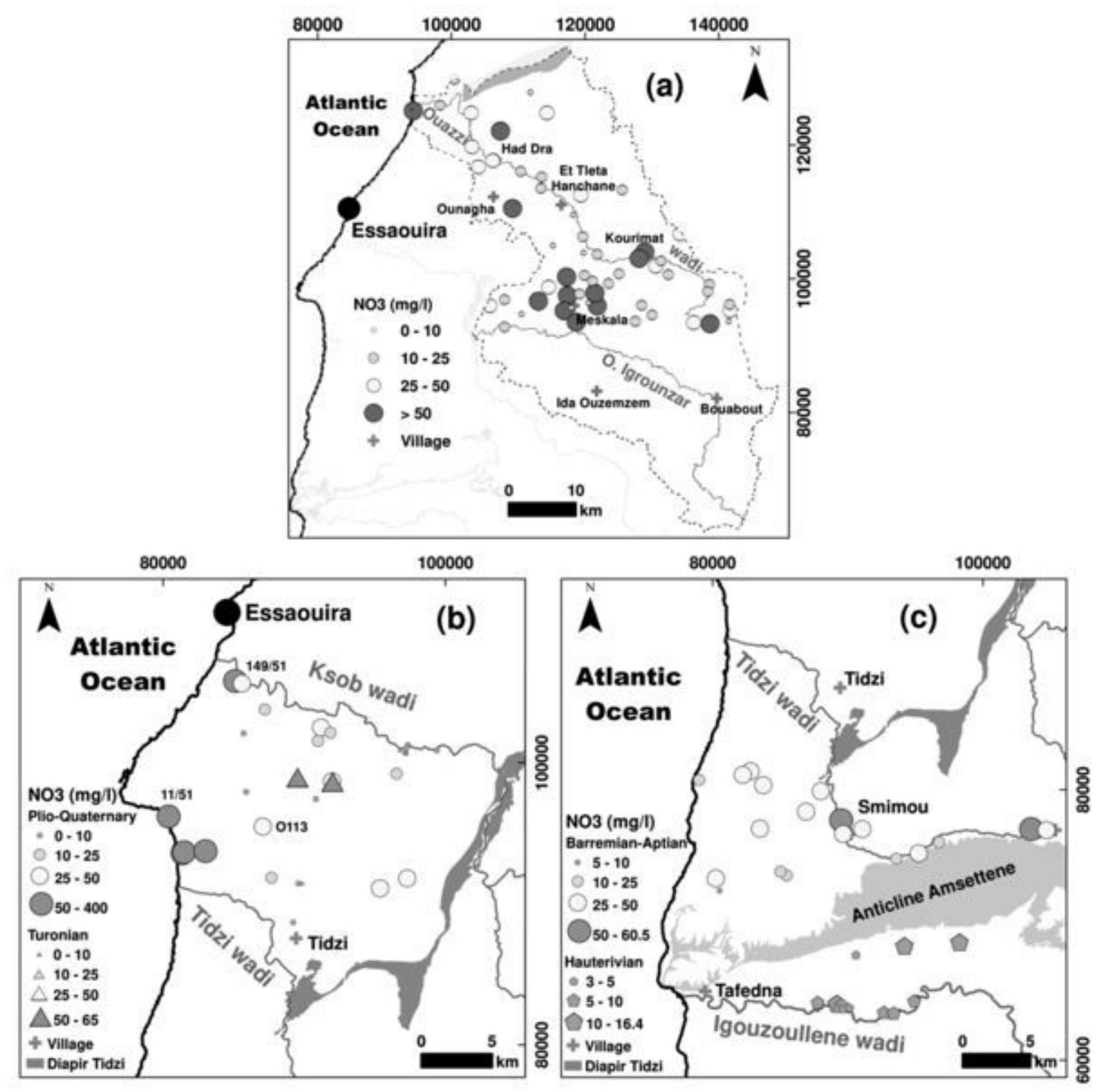

Figure 14

Spatial distribution of NO3- content in groundwater of (a) Cenomanian-Turonian, (b) Plio-Quaternary and Turonian, and (c) Barremian-Aptian and Hauterivian aquifers 

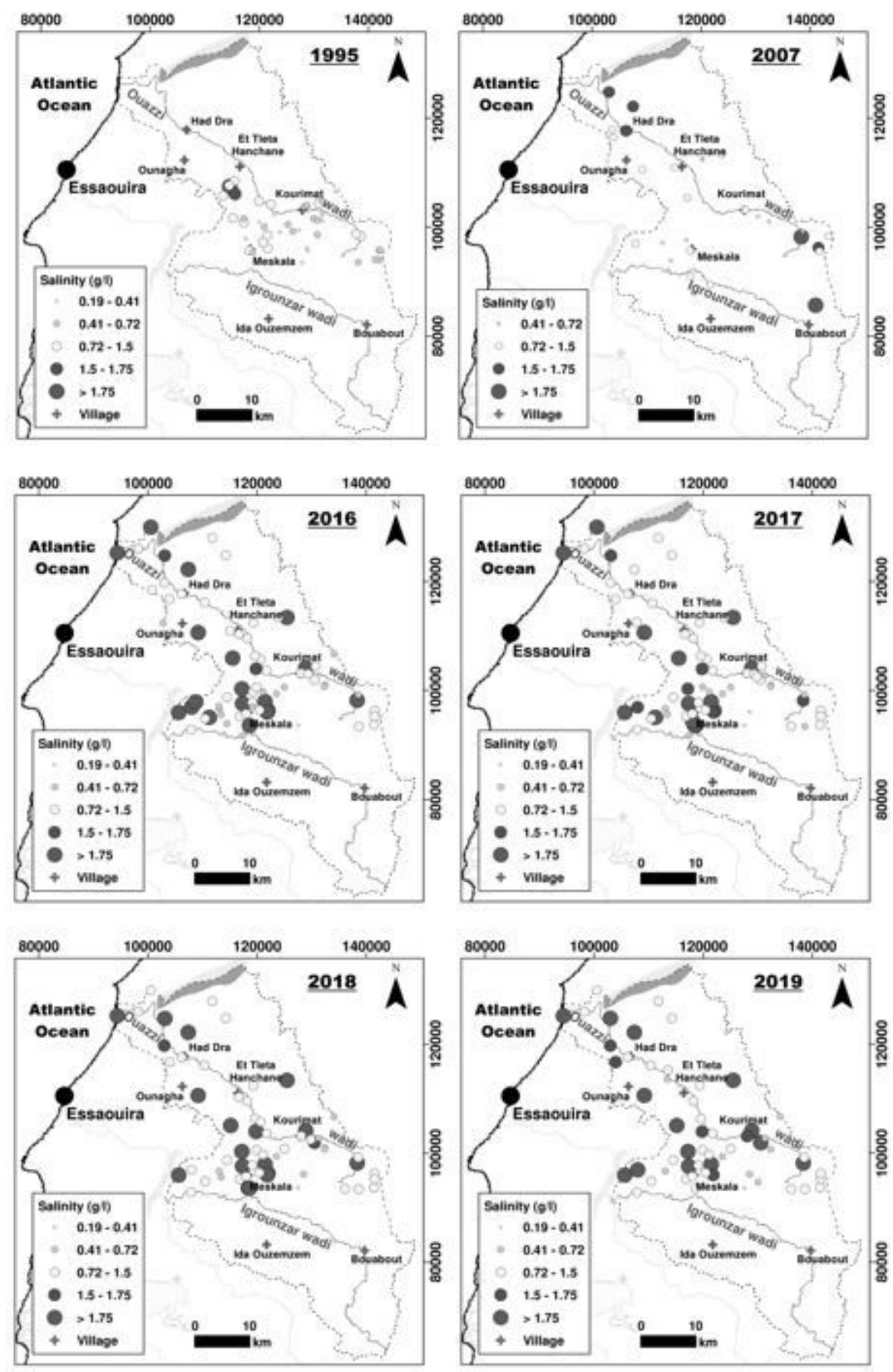

Figure 15

Spatial distribution of salinity in Cenomanian-Turonian aquifer 

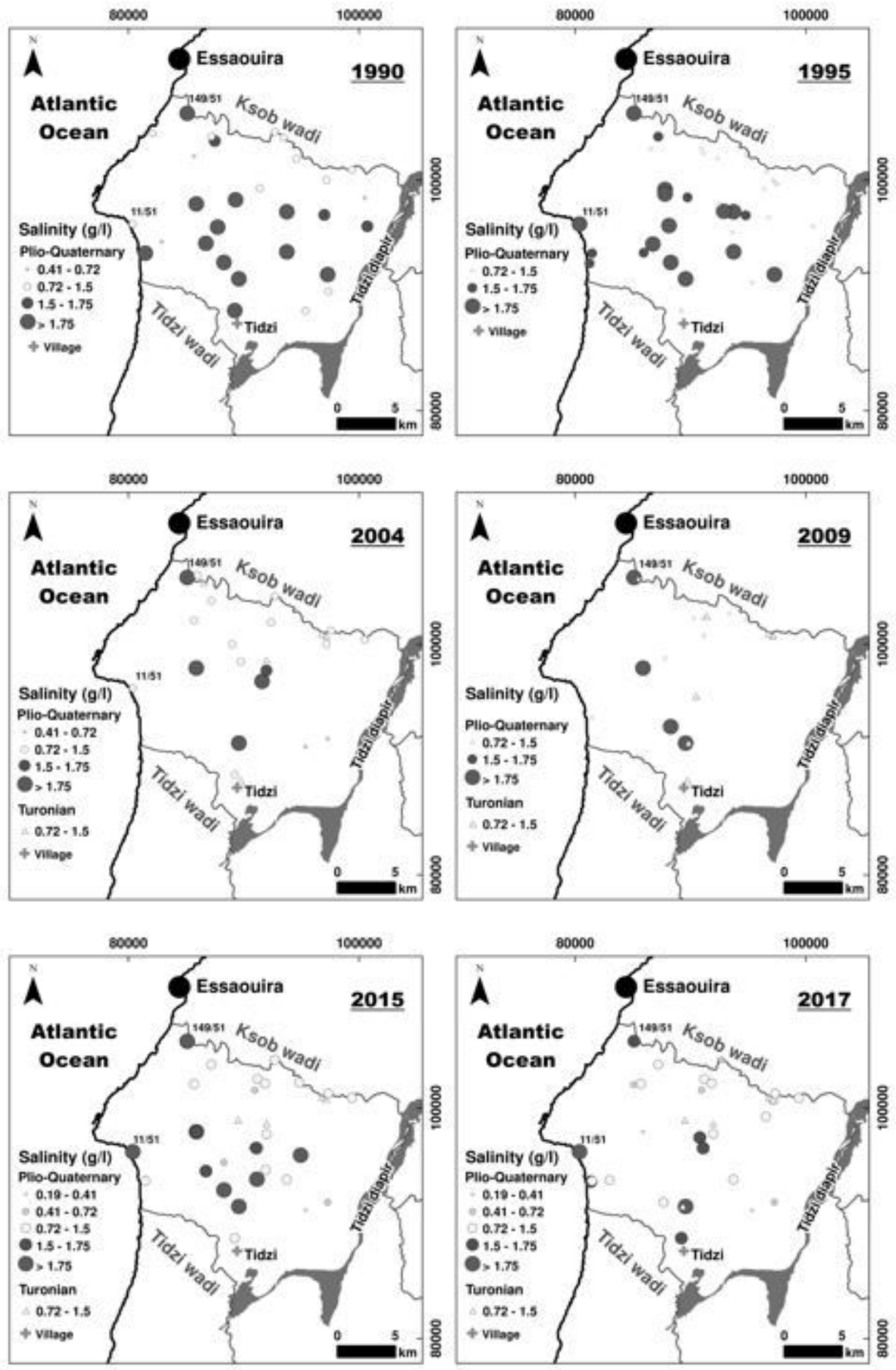

Figure 16

Spatial distribution of salinity in Plio-Quaternary and Turonian aquifers 


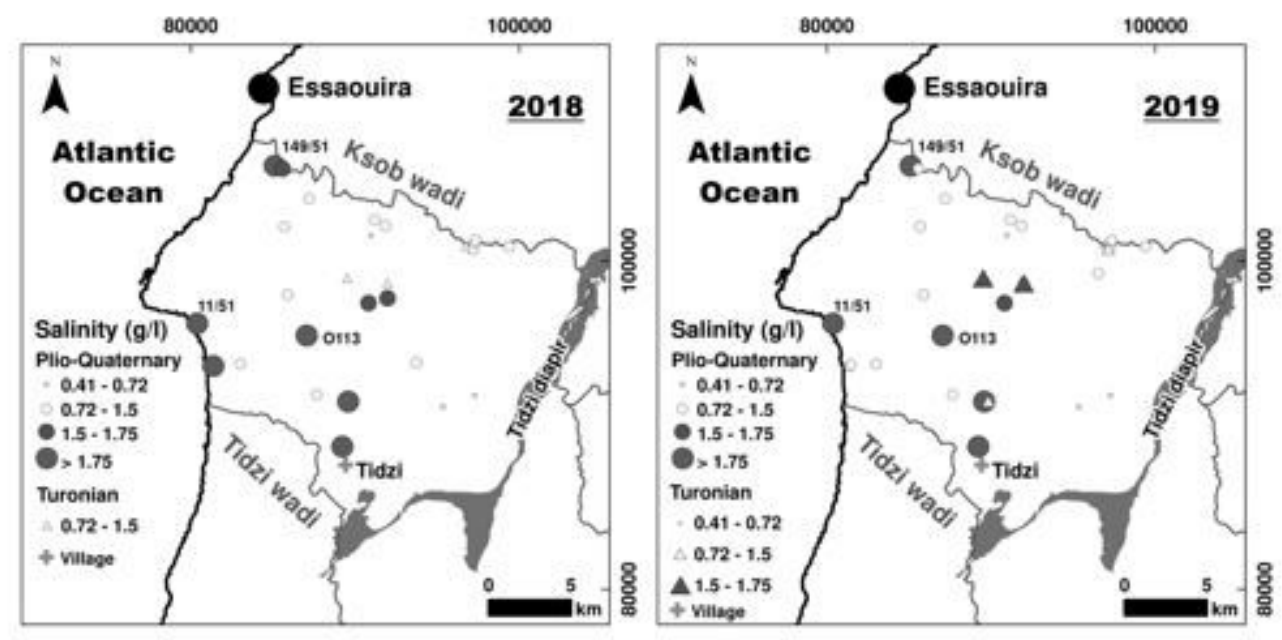

Figure 17

Spatial distribution of salinity in Plio-Quaternary and Turonian aquifers 

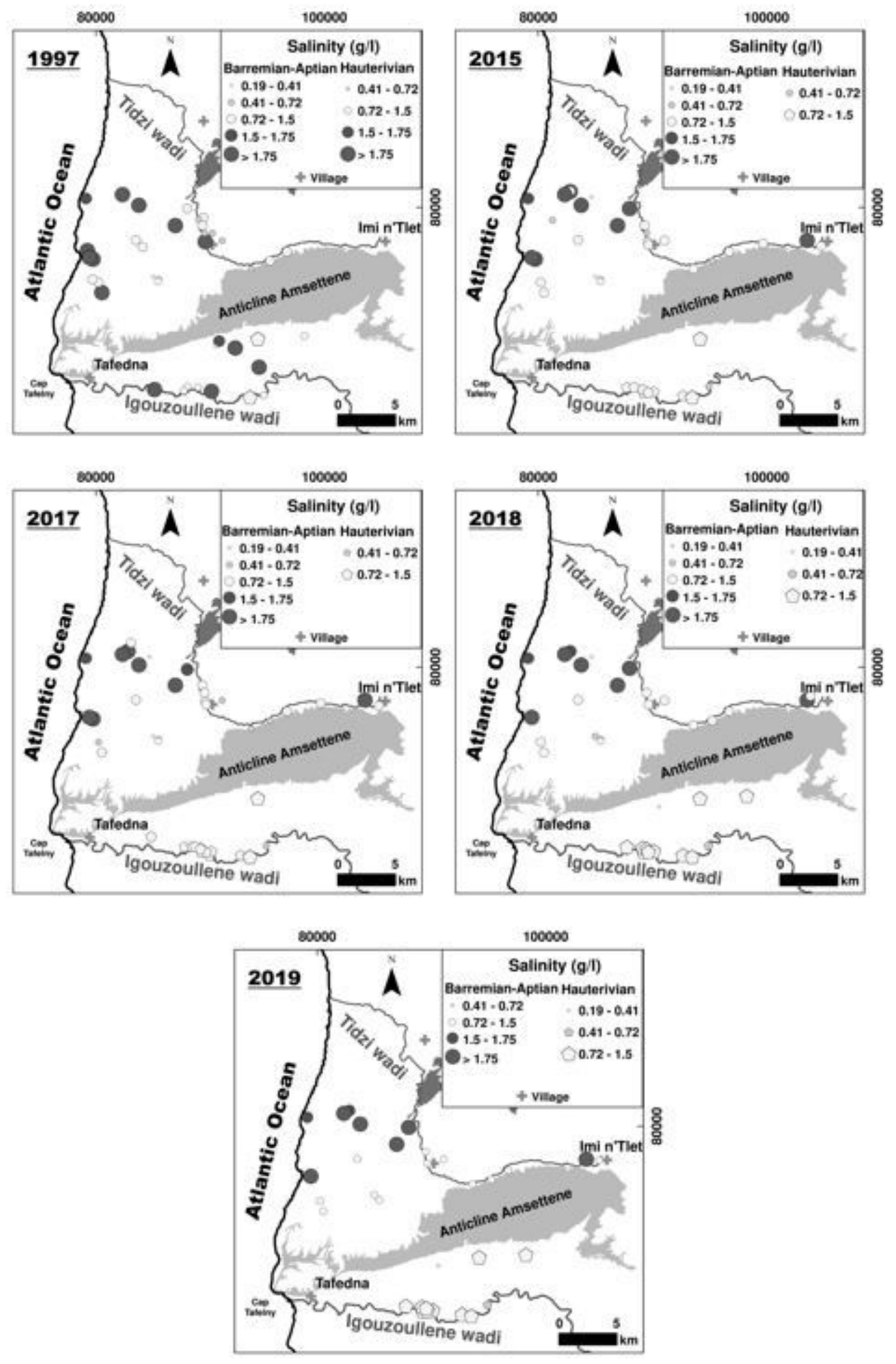

Figure 18

Spatial distribution of salinity in Barremian-Aptian and Hauterivian aquifers 

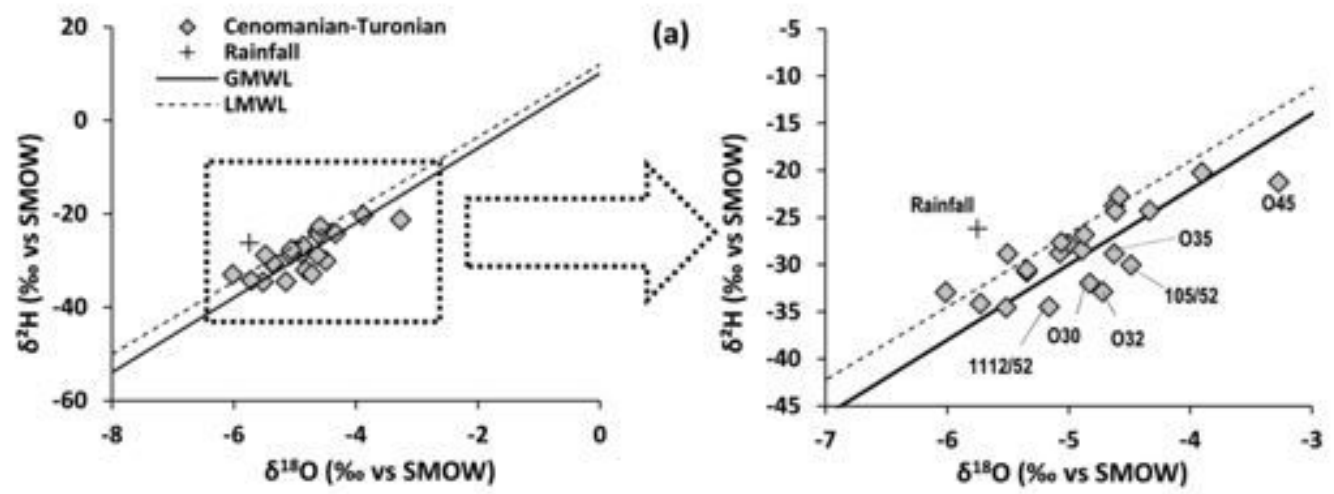

(b)

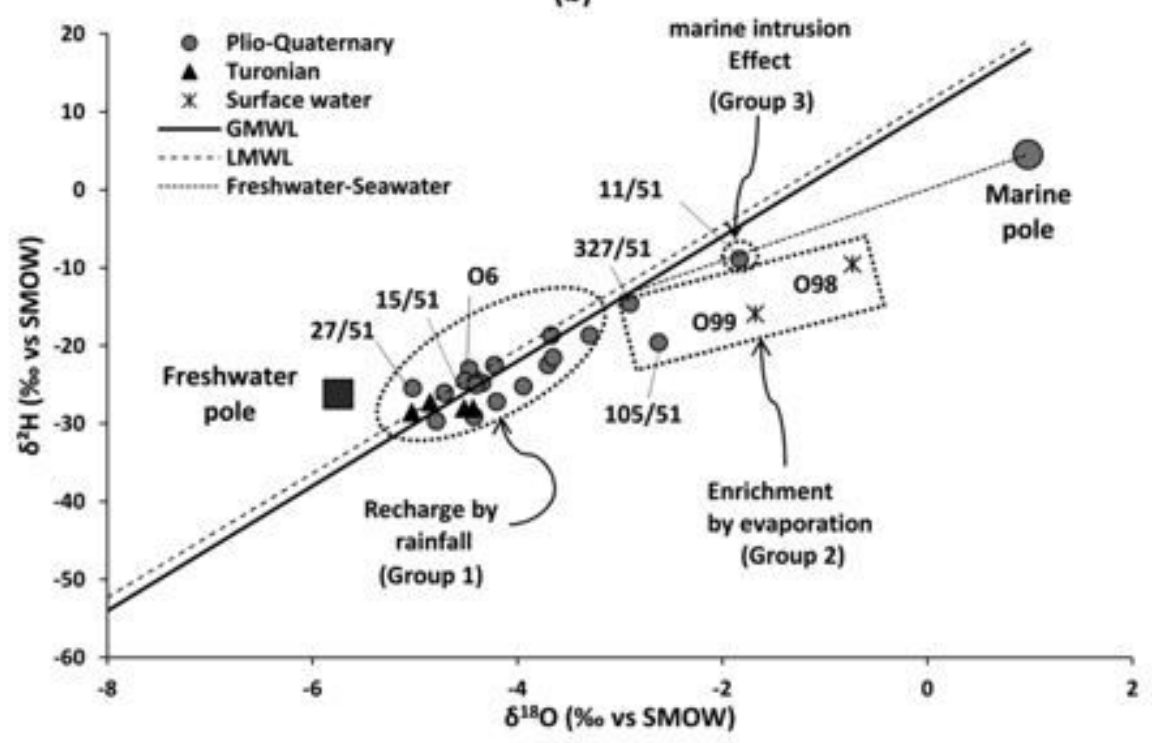

Figure 19

$\delta^{2} \mathrm{H}-\delta 180$ correlation diagram of the groundwater of (a) the Canomanian-Turonian aquifer and (b) the Plio-Quaternary and Turonian aquifers

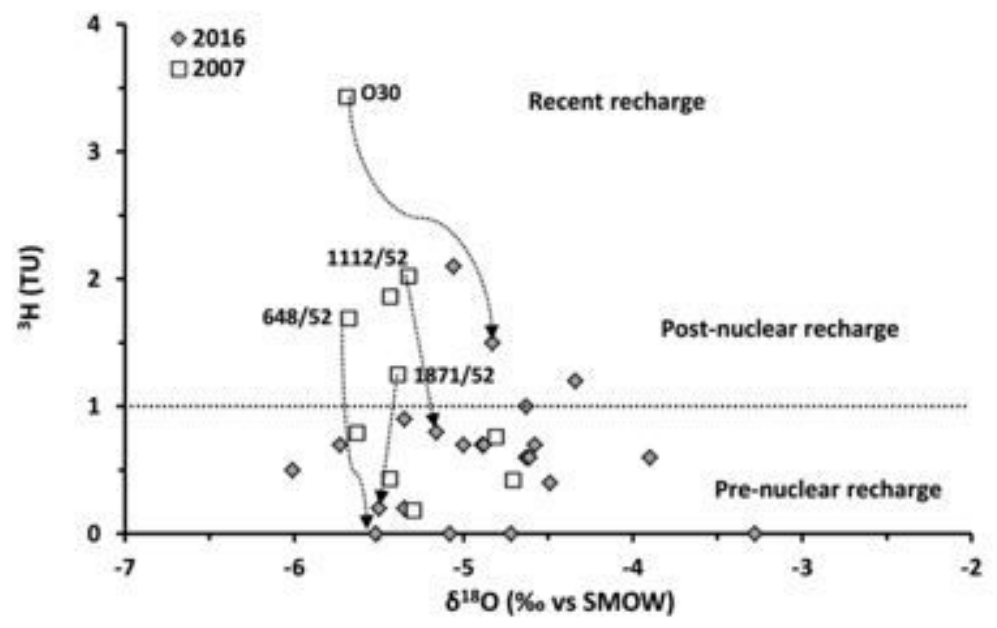

Figure 20 
Relation oxygen-18 and tritium content of Cenomanian-Turonian groundwater
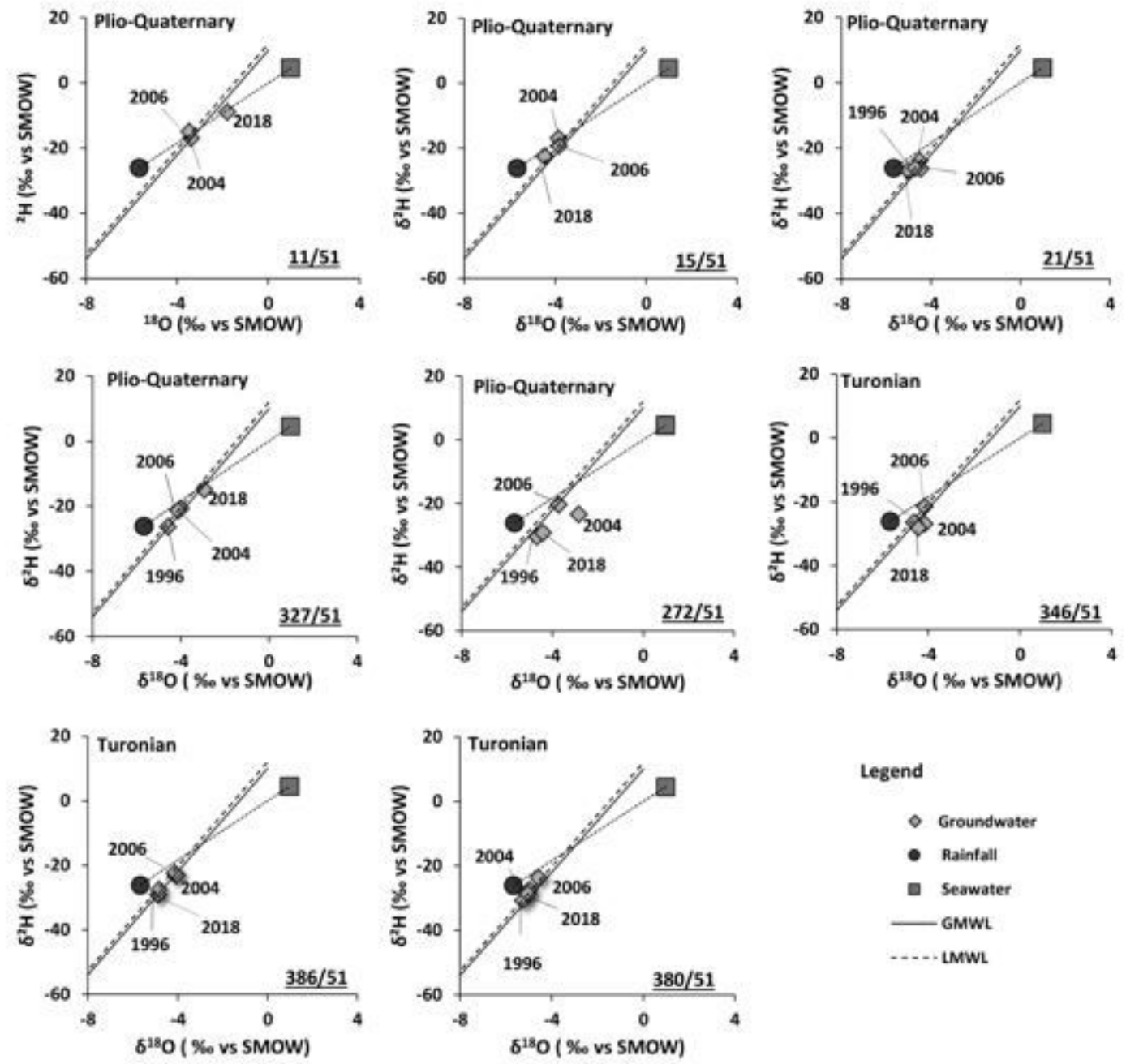

Figure 21

Isotopic contents evolution of the groundwater of the Plio-Quaternary and Turonian aquifers 

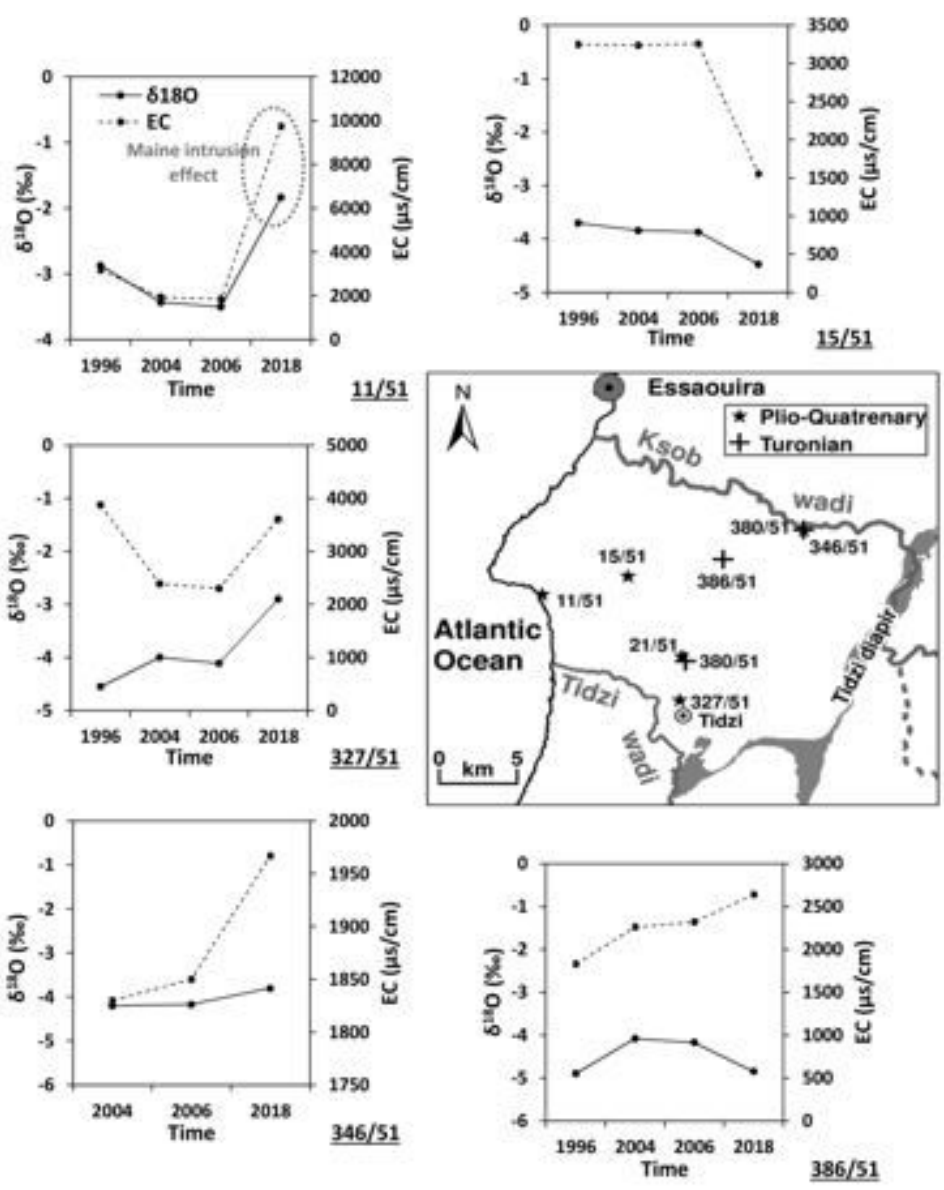
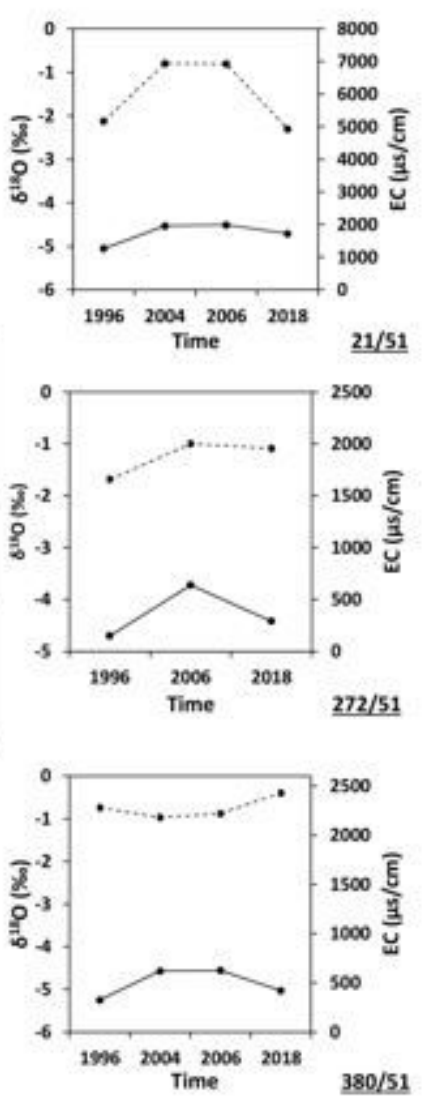

Figure 22

Evolution temporal of 180 content and Electrical Conductivity of points capturing Plio-Quaternary and Turonian aquifers

\section{Supplementary Files}

This is a list of supplementary files associated with this preprint. Click to download.

- Appendixrevised.docx

- GraphicalAbstractImagerevised.docx 